\title{
High natural erosion rates are the backdrop for present-day soil erosion in the agricultural Middle Hills of Nepal
}

\author{
A. J. West ${ }^{1}$, M. Arnold ${ }^{2, *}$, G. Aumaître ${ }^{2, *}$, D. L. Bourlès ${ }^{2, *}$, K. Keddadouche ${ }^{2, *}$, M. Bickle ${ }^{3}$, and T. Ojha ${ }^{4}$ \\ ${ }^{1}$ Department of Earth Sciences, University of Southern California, Los Angeles, CA 90089, USA \\ ${ }^{2}$ Aix-Marseille Université, CNRS-IRD-Collège de France, UM 34 CEREGE, Technopôle de l'Environnement \\ Arbois-Méditerranée, BP80, 13545 Aix-en-Provence, France \\ ${ }^{3}$ Department of Earth Sciences, University of Cambridge, Cambridge CB2 3EQ, UK \\ ${ }^{4}$ Department of Geosciences, University of Arizona, Tucson, AZ 85721, USA \\ ${ }^{*}$ The ASTER Team
}

Correspondence to: A. J. West (joshwest@usc.edu)

Received: 9 July 2014 - Published in Earth Surf. Dynam. Discuss.: 11 August 2014

Revised: 1 May 2015 - Accepted: 13 May 2015 - Published: 23 July 2015

\begin{abstract}
Although agriculturally accelerated soil erosion is implicated in the unsustainable environmental degradation of mountain environments, such as in the Himalaya, the effects of land use can be challenging to quantify in many mountain settings because of the high and variable natural background rates of erosion. In this study, we present new long-term denudation rates, derived from cosmogenic ${ }^{10} \mathrm{Be}$ analysis of quartz in river sediment from the Likhu Khola, a small agricultural river basin in the Middle Hills of central Nepal. Calculated long-term denudation rates, which reflect background natural erosion processes over $1000+$ years prior to agricultural intensification, are similar to present-day sediment yields and to soil loss rates from terraces that are well maintained. Similarity in short- and long-term catchment-wide erosion rates for the Likhu is consistent with data from elsewhere in the Nepal Middle Hills but contrasts with the very large increases in short-term erosion rates seen in agricultural catchments in other steep mountain settings. Our results suggest that the large sediment fluxes exported from the Likhu and other Middle Hills rivers in the Himalaya are derived in large part from natural processes, rather than from soil erosion as a result of agricultural activity. Catchment-scale erosional fluxes may be similar over short and long timescales if both are dominated by mass wasting sources such as gullies, landslides, and debris flows (e.g., as is evident in the landslide-dominated Khudi Khola of the Nepal High Himalaya, based on compiled data). As a consequence, simple comparison of catchment-scale fluxes will not necessarily pinpoint land use effects on soils where these are only a small part of the total erosion budget, unless rates of mass wasting are also considered. Estimates of the mass wasting contribution to erosion in the Likhu imply catchment-averaged soil production rates on the order of $\sim 0.25-0.35 \mathrm{~mm} \mathrm{yr}^{-1}$, though rates of mass wasting are poorly constrained. The deficit between our best estimates for soil production rates and measurements of soil loss rates supports conclusions from previous studies that terraced agriculture in the Likhu may not be associated with a large systematic soil deficit, at least when terraces are well maintained, but that poorly managed terraces, forest, and scrubland may lead to rapid depletion of soil resources.
\end{abstract}




\section{Introduction}

The loss of soil by erosion can present an environmental challenge with potentially grave social and economic consequences, including decreased agricultural productivity $(\mathrm{Pi}-$ mentel et al., 1995; Montgomery, 2007), damage to hydropower infrastructure and reduction of reservoir life spans (e.g., Harden, 1993), and increased flooding hazards (e.g., Costa, 1975). In steep mountain environments, deforestation and agricultural intensification have been linked to increased soil loss (Eckholm, 1975; Hewawasam et al., 2003; Rapp, 1975; Swanson and Dyrness, 1975) and associated "environmental degradation" (Ives and Messerli, 1989). Unsustainable soil loss potentially puts at risk rural mountain communities that rely on the economy of local agriculture and that are highly susceptible to sediment-related hazards in downstream environments (Brown, 1981). Restoration of dense vegetation has been shown to remediate erosional losses (Vanacker et al., 2007), but population pressure and intense competition for land use means that permanent re-vegetation is not always possible or sustainable for rural communities. Techniques such as terracing and low-till agriculture can mitigate erosional losses (Chow et al., 1999; van Dijk and Bruijnzeel, 2003; Gardner and Gerrard, 2003; Inbar and Llerena, 2000; Montgomery, 2007; Morgan, 2005), but significant questions remain about the extent to which specific agricultural practices prevent or exacerbate erosion and land degradation (Bai et al., 2008). Answering these questions is critical to optimizing the strategy for preventing unsustainable soil loss in mountain regions.

One major challenge lies in assembling robust data on how erosion rates change under mountain agriculture. In particular, it not always straightforward to define baseline "natural" rates of erosion for comparison to the present-day rates that are influenced by agricultural land uses. The simple observation of rapid erosion from hillslopes and high sediment fluxes in rivers does not distinguish agricultural effects, because background rates of landscape denudation are high in mountain environments. Plot studies are frequently used to compare soil loss under different land uses (e.g., Boix-Fayos et al., 2006; Gardner and Gerrard, 2003; Hudson, 1993; Merz, 2004; Morgan, 2005; Mutchler et al., 1970). Plots provide valuable information but face methodological challenges (e.g., Boardman, 2006; Bruijnzeel and Critchley, 1996; Toy et al., 2002) and are inherently small in scale and site-specific. Other studies have compared catchments with different land use make-up, but natural spatial heterogeneity can make it difficult to find appropriate catchments that effectively isolate variables such as agricultural activity (e.g., Heimsath, 1993).

One additional source of information may come from comparing subannual to decadal sediment fluxes with erosion rates integrated over longer periods of time (Hewawasam et al., 2003; Vanacker et al., 2007, 2014; Reusser et al., 2015). The concentration of the cosmogenic nuclide ${ }^{10} \mathrm{Be}$ in quartz separated from river sands (hereafter " ${ }^{10} \mathrm{Be}_{\mathrm{qtz}}$ ") can be used to infer long-term denudation rates, typically integrated over $\sim 1000+$ year timescales (von Blanckenburg, 2006; Brown et al., 1995; Granger et al., 1996). Land use can change ${ }^{10} \mathrm{Be}_{\mathrm{qtz}}$ itself, but such effects are often relatively small (see further discussion below, and Appendix A3). Thus in many cases this method effectively captures "natural background" rates not strongly affected by agricultural activity. Insights into catchment-scale effects of land use may then emerge by comparing ${ }^{10} \mathrm{Be}_{\mathrm{qtz}}$-derived erosion rates with sediment fluxes measured over more recent agricultural times (e.g., 1-10+ years). Specifically, presentday sediment fluxes may be increased relative to long-term erosion rates as a result of active soil loss from agricultural areas, or they may be reduced if historical agriculture has led to pervasive depletion of fine soil material. Hewawasam et al. (2003) and Vanacker et al. (2007) used such comparisons to show that deforestation has dramatically increased erosion rates in the highlands of Sri Lanka (presently dominated by tea plantations) and the Andes of Ecuador (dominated by mixed cropland and pasture). Similarly, Reusser et al. (2015) found that upland erosion rates increased during intensive land use in the Appalachian piedmont of the southeastern United States. Restoring vegetation cover in Ecuador returned catchment erosion rates to background values (Vanacker et al., 2007), as did soil conservation practices in the United States (Reusser et al., 2015). Vanacker et al. (2014) noted that even degraded lands in the Spanish Baetic Cordillera show little difference between short- and long-term rates, perhaps because natural vegetation was not a major erosional inhibitor in this region even before agriculture. They hypothesized that the extent of deviation from natural vegetation cover exerts a first-order control on the magnitude of anthropogenic acceleration of erosion.

Additional comparative studies such as these promise to add information about how land degradation depends on the setting and the type of agricultural activity in mountain environments. In this study, we focus on the Middle Hills of the Nepal Himalaya, where there is a rich literature on soil erosion (e.g., Gardner and Jenkins, 1995; Shrestha et al., 1997; Blaikie and Sadeque, 2000; Merz, 2004; amongst many others) and where the concept of dwindling Himalayan soil resources and the associated theory of Himalayan environmental degradation (Eckholm, 1975; Ives and Messerli, 1989) have been widely discussed (e.g., Asia Development Bank and ICIMOD, 2006; Sitaula et al., 2005). High rates of soil loss have been frequently observed in association with degraded lands in the Middle Hills region (e.g., Burton et al., 1989; Gardner and Jenkins, 1995; Merz, 2004). Meanwhile, plot-erosion investigations have suggested that traditional terracing practices are associated with relatively low rates of soil loss (Gardner and Gerrard, 2003; Smadja, 1992; Tiwari et al., 2009), indicating that terraces can be effective at mitigating erosion. However, such plot-scale studies may not capture losses from terrace risers (Bruijnzeel and Critchley, 
1996; Toy et al., 2002), and it is unclear how the plot study results relate to degradation at the wider landscape scale in the Middle Hills (Hamilton, 1987).

The extensive previous work in Nepal studying rates of agricultural soil loss has been complemented by no less exhaustive efforts investigating erosion and denudation rates across large-scale climatic and tectonic gradients in the central Himalaya (e.g., Wobus et al., 2005; Gabet et al., 2008; Lupker et al., 2012; Andermann et al., 2012; Godard et al., 2014; see Fig. 1). The data sets resulting from this work show that long-term (millennial and longer timescale) erosion rates are highly spatially variable and controlled to first order by tectonic activity, with higher erosion rates north of the thrust faults that demarcate the transition from the Middle Hills to High Himalayan topography (Wobus et al., 2005; Godard et al., 2014). A comparison of short- and long-term erosion rates thus needs to consider spatial differences between catchments together with any temporal evolution due to land use change. There are some sites in Nepal where short- and long-term erosion rates have both been measured in the same catchment, specifically the High Himalayan Khudi Khola (Gabet et al., 2008; Gallo and Lavé, 2014; Godard et al., 2012; Niemi et al., 2005; Puchol et al., 2014) and some of the large river basins (Andermann et al., 2012; Lupker et al., 2012). Data from these catchments are discussed in detail in Sect. 5, but existing sites where long-term erosion rates have been measured previously do not overlap with the locations where erosion has been studied in detail in agricultural systems in the Middle Hills. As a consequence, despite the wealth of prior research on erosion in Nepal, detailed comparisons of erosion rates over relatively short and long timescales have thus far not been widely explored in the agricultural context in this region.

To shed additional light on the problem of soil degradation associated with agriculture in the Himalaya, here we present new cosmogenic ${ }^{10} \mathrm{Be}_{\text {qtz }}$ data from well-studied agricultural catchments in the Nepal Middle Hills, and we compare these data with previously determined sediment yields, soil loss rates from plots, and first-order estimates of mass wasting fluxes. By comparing two catchments with varying extents of agricultural land use, and by setting our results in the context of other ${ }^{10} \mathrm{Be}_{\mathrm{qtz}}$ and sediment flux data from Nepal, we attempt to gain additional insight into the extent of agricultural reworking of the Himalayan landscape.

\section{Study site}

The focus of this study is on the Likhu Khola Valley, an east-west-trending river valley in central Nepal that lies immediately north of the Kathmandu Valley (at approximately $27^{\circ} 50^{\prime} \mathrm{N}, 85^{\circ} 20^{\prime} \mathrm{E}$; Fig. 2). The proximity of the Likhu Valley to the city of Kathmandu ( $\sim 50-60 \mathrm{~km}$ distance) has led to intense population pressure on this rural environment. The Likhu Khola itself is a tributary of the Trisuli River, which flows via the Narayani River to the Ganges. The elevation of the Likhu drainage basin ranges from 530 to $2720 \mathrm{~m}$. The bedrock is composed of Kathmandu Complex gneisses and schists, overlain by a deep weathered zone (several meters' depth) and loamy soils up to 2-3 m thickness, with typical A horizons $10-40 \mathrm{~cm}$ thick and B horizons $10-220 \mathrm{~cm}$ thick (Shrestha, 1997). Slopes in the Likhu are steep, at 10-45 ${ }^{\circ}$ (mean slopes for the Likhu and its subcatchments are shown in Table 1). The Likhu Fault, a geologic structure associated with but distinct from the Main Central Thrust (MCT), is thought to run with an east-west strike through the bottom of the valley (Fig. 2). Annual rainfall is approximately $2500 \mathrm{~mm}$, as measured at the Kakani meteorology station on the ridge that defines the southern watershed boundary of the Likhu; rainfall shows complex spatial variability across the catchment (Gardner and Jenkins, 1995), as is often the case in mountain environments.

Natural land cover in the Likhu catchment is predominantly subtropical and tropical hardwoods at lower elevations and mixed broadleaf forest at higher elevations, with some mixed pine forest of Pinus roxburghii (Gardner and Gerrard, 2002; Shrestha et al., 2007). Agricultural practices in the Nepal Middle Hills include rainfed bari terraces and irrigated khet terraces. Bari terraces typically have sloping surfaces and are used primarily for maize production. Bari terraces in the Likhu are gently sloping $\left(\sim 5^{\circ}\right.$, usually sloping outwards and/or sideways), and about $2-10 \mathrm{~m}$ wide, with typical riser heights up to a few meters (see details in Gardner and Gerrard, 2003). Riser angles are typically $>60^{\circ}$, though angles on slumped risers are lower. Crops on typical bari terraces in Nepal depend on monsoon rainfall and are usually cycled between maize (Zea mays L.), sometimes interplanted with legumes (grown May-August), and millet (Eleusine coracana L., grown August-December). Khet terraces are often built with bunds (raised edges designed as barriers to runoff) and flooded. Khet terraces are typically used to grow irrigated paddy rice (Oryza sativa L.), sometimes followed by wheat (Triticum aestivum L.) or other winter crops (Shrestha et al., 2006). Wooden plows and hand hoes are used on both bari and khet lands; fertilizers include both farmyard manure and chemical fertilizer. Some of the forested lands are "degraded" due to grazing and partial deforestation, particularly harvesting of sal (Shorea robusta) wood, and some of the land formerly in cultivation has been abandoned and is now degraded shrubland. Other forested lands, particularly on steep slopes, have remained relatively pristine (Gardner and Gerrard, 2002; Shrestha et al., 2007).

In this study, we focus specifically on the Bore Khola (Fig. 3; Table 1), a subcatchment of the Likhu Khola with total catchment area $4.8 \mathrm{~km}^{2}$, spanning elevations from $\sim 670$ to $2200 \mathrm{~m}$. Of the catchment area, $\sim 50 \%$ was forested and $\sim 40 \%$ was terraced (30\% khet and $10 \%$ bari) when sediment fluxes were measured in the early 1990s (see below). The main Bore Khola has two headwaters: the upstream Bore (catchment area $2.0 \mathrm{~km}^{2}$ ), and the Chinnya Khola (area 


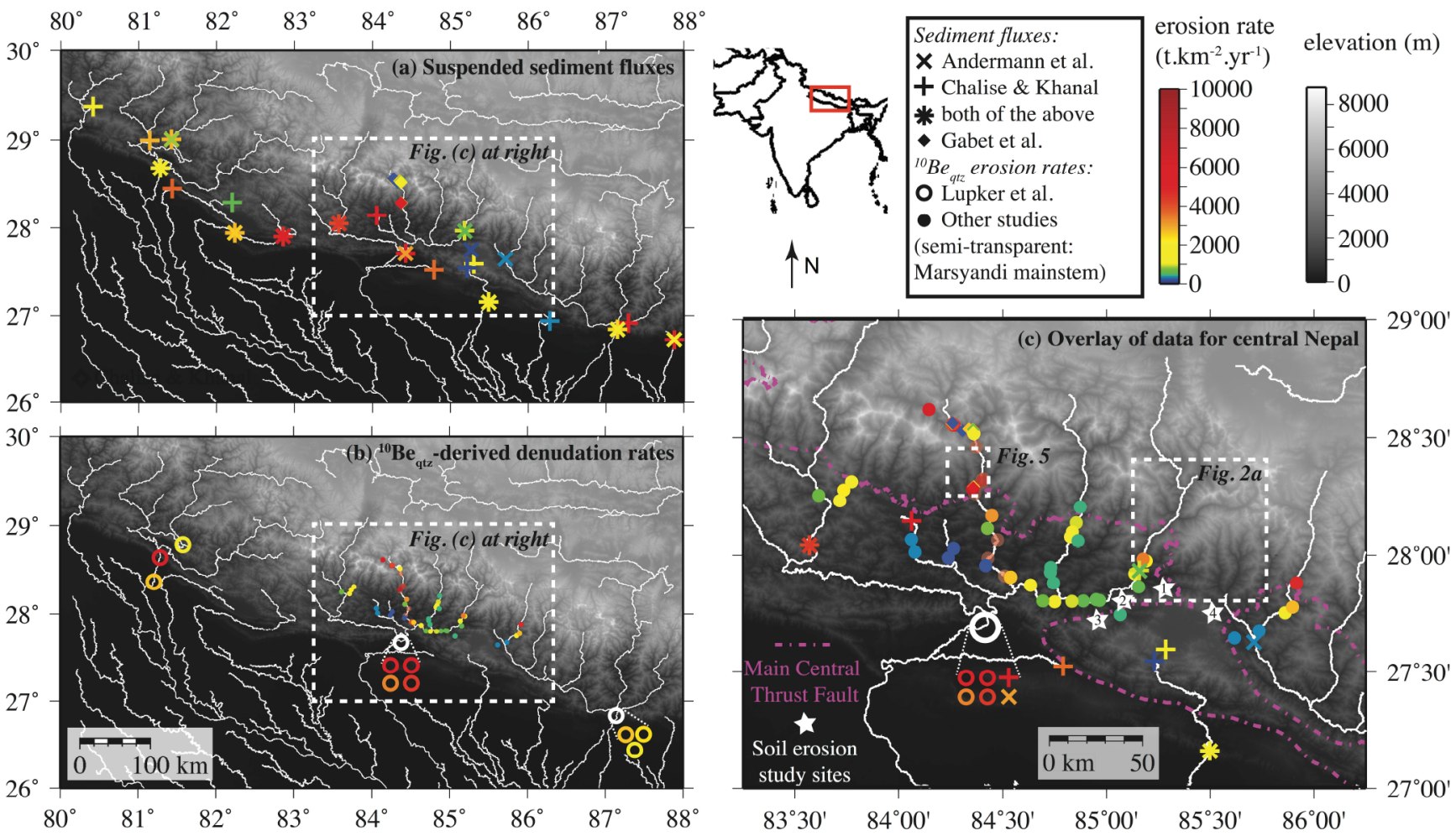

Figure 1. Map of Nepal showing erosion rate data collected in previous studies. Grayscale background shows elevation from SRTM digital elevation map at $\sim 90 \mathrm{~m}$ resolution. Data points are color-coded by erosion rate. (a) Sediment fluxes from Chalise and Khamal (1997) and Andermann et al. (2012), with overlain symbols representing sites with data from both studies. (b) Denudation rates determined from ${ }^{10} \mathrm{Be}_{\mathrm{qtz}}$ from Godard et al. (2012), Godard et al. (2014), Lupker et al. (2012), and Wobus et al. (2005). White circles are expanded to show data collected from multiple times or grain sizes by Lupker et al. (2012). (c) Magnified scale of central Nepal region showing data from (a) and (b) along with location of several previous studies of agricultural soil erosion identified from published literature: (1) Likhu Khola (Gardner and Jenkins, 1995; location of this study), (2) Kulekhani (Upadhaya et al., 1991), (3) Pokhare Khola (Tiwari et al., 2008), and (4) Jhiku Khola and Kavre catchments (e.g., Merz, 2004).
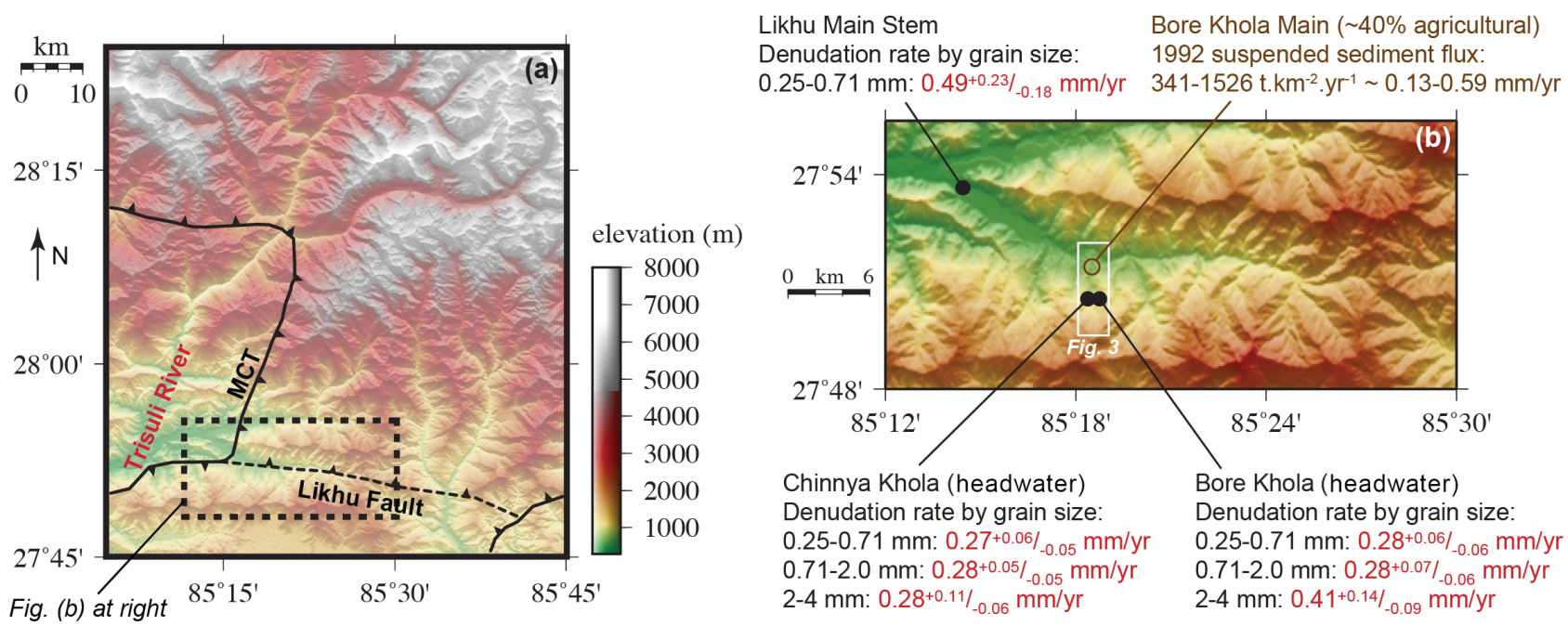

Figure 2. Map of central Nepal north of the Kathmandu Valley (a) and close-up map of the Likhu Khola (b), showing sampling sites for river sediment and corresponding ${ }^{10} \mathrm{Be}_{\mathrm{qtz}}$-derived long-term denudation rates (see text). MCT: Main Central Thrust. 
Table 1. Characteristics of the study catchments in the Likhu Khola.

\begin{tabular}{llllllll}
\hline $\begin{array}{l}\text { Catchment } \\
\text { (see map, Fig. 2) }\end{array}$ & $\begin{array}{l}\text { Catchment } \\
\text { area }\left(\mathrm{km}^{2}\right)\end{array}$ & $\begin{array}{l}\text { Mean slope }^{\mathrm{a}} \\
(\mathrm{deg})\end{array}$ & Forest & Khet & Bari & Grassland & Shrub \\
\hline Bore Khola & 2.0 & 29.8 & 81.9 & 5.7 & 11.6 & 0.9 & 0 \\
Chinnya Khola & 0.6 & 32.0 & 70.7 & 5.4 & 21.7 & 1.9 & 0.3 \\
Bore main stem & 4.8 & 26.1 & 52.0 & 30.5 & 10.2 & 1.2 & 6.1 \\
Likhu main stem & 166.4 & 25.6 & 15.4 & 30.6 & 16.6 & 15.4 & 22 \\
\hline
\end{tabular}

a Mean slope calculated from $30 \mathrm{~m}$ DEM.

$\mathrm{b}$ Land use percentages from Gardner and Jenkins, 1995, and maps therein. Khet: irrigated terraces; bari: rainfed terraces.

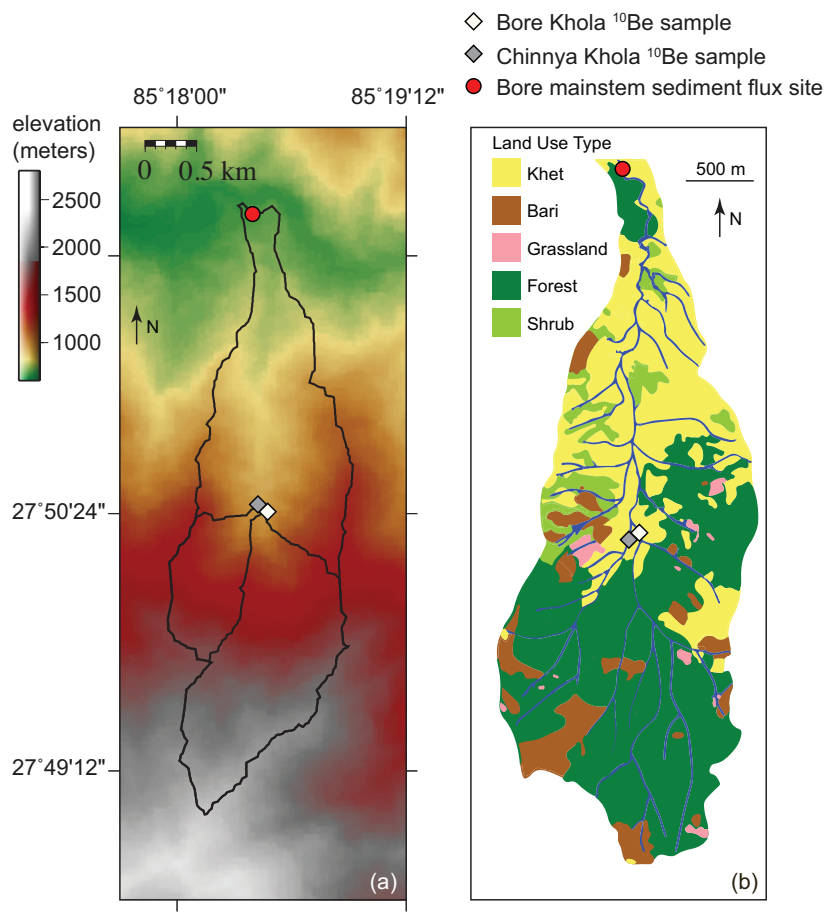

Figure 3. Detailed maps of elevation (a) and land use (b) of the Bore Khola subcatchment of the Likhu Khola. The Bore Khole includes the Bore and Chinnya headwater catchments that were sampled for determining long-term denudation rates from ${ }^{10} \mathrm{Be}_{\mathrm{qtz}}$. Note that these low-order, headwater catchments are predominantly forested with little agricultural land use, so they are expected to provide a robust background erosion rate. Land use map is adapted from Gerrard and Gardner (1999), with unknown projection that does not exactly match panel (a). Bari are rainfed terraces; khet are irrigated terraces (see text).

$\left.0.6 \mathrm{~km}^{2}\right)$, both of which are predominantly forested $(>70$ $80 \%$; Table 1). For comparison, we also consider the larger Likhu Khola Basin (catchment area $166.4 \mathrm{~km}^{2}$ ) just upstream of its confluence with the Trisuli (shown in Fig. 2). Across this larger Likhu Basin, the predominant land use during the study period was khet terraces (30.6\% total catchment area), with some bari (16.6\% area) and grassland (15.4\%). The remainder of land was forest $(15.4 \%)$ and scrubland (Table 1$)$.

\section{Methods}

\subsection{Short-term erosion rates}

Data on short-term (annual to decadal) erosion rates were assembled from previously published measurements of soil loss from plots (Gardner and Gerrard, 2001, 2002, 2003), quantification of sediment transported by streams (Brasington and Richards, 2000), and mapping of the distribution and volumes of landslides, slumps, and debris flows over multiple years (Gerrard and Gardner, 1999, 2000, 2002). The methods used in these previously published studies are summarized briefly here.

Plot studies of soil loss were conducted in 1992 and 1993 using existing agricultural ditches at the base of terrace risers to channel runoff and sediment into collection drums. Multiple terrace plots were selected and studied in order to capture a representative range of agricultural practices. Runoff and suspended sediment were determined after storms from material in the collection drums (Gardner and Gerrard, 2001, 2002, 2003).

Stream sediment transport was measured by installing gauging stations with pressure transducers monitoring stream stage height. Sediment concentrations were determined from depth-integrated sampling at regular (biweekly) intervals supplemented by storm event sampling, and by turbidity loggers. Fluxes for 1992 were determined from rating curves (Brasington and Richards, 2000).

Mass wasting fluxes were measured during 1991, 1992, and 1993 by identifying, mapping, and measuring all slope failures over this time period (Gerrard and Gardner, 1999, 2000, 2002). Most failures were either slumps or debris slides. Dimensions of failures were mapped in the field and used to calculate volumes lost by mass wasting each year. Connectivity of failures to the stream system was used to determine a sediment delivery ratio to streams of $50 \%$ on average over the three years studied (Gerrard and Gardner, 2000).

\subsection{Measurement of ${ }^{10} \mathrm{Be}_{\text {qtz }}$}

Rates of natural background erosion were calculated from the concentration of in situ-produced ${ }^{10} \mathrm{Be}$ in quartz $\left({ }^{10} \mathrm{Be}_{\mathrm{qtz}}\right)$ 
separated from stream sediments. Sediment samples $(\sim 5 \mathrm{~kg}$ each) were collected from material in active transport in the streambed of the headwater Bore Khola and Chinnya Khola catchments, and of the higher-order Likhu Khola main stem (Figs. 2, 3). Samples were returned to the UK and sieved to size fractions $<0.25 \mathrm{~mm}, 0.25-0.71 \mathrm{~mm}, 0.71-2.0 \mathrm{~mm}$, and $2.0-4.0 \mathrm{~mm}$. Quartz grains in the $<0.25 \mathrm{~mm}$ fraction are too small to determine the concentrations of ${ }^{10} \mathrm{Be}$ in quartz. The other three size fractions were analyzed separately for the Bore and Chinnya samples. There was little coarse-grained material in the Likhu main stem sample, so only the $0.25-$ $0.71 \mathrm{~mm}$ fraction was processed. Sample processing and ${ }^{10} \mathrm{Be}$ analysis was completed at the Cosmogenic Nuclides National Laboratory (LN2C) and the French national AMS facility ASTER at CEREGE (Aix-en-Provence, France). Samples were leached in HF to separate quartz and to remove meteoric contamination (Kohl and Nishiizumi, 1992). AMS analyses were calibrated against NIST SRM 4325 based on a ${ }^{10} \mathrm{Be} /{ }^{9} \mathrm{Be}$ ratio of $(2.79 \pm 0.03) \times 10^{-11}$ and a ${ }^{10} \mathrm{Be}$ halflife of $(1.36 \pm 0.07) \times 10^{6}$ years (Nishiizumi et al., 2007). Blanks run together with the samples had ${ }^{10} \mathrm{Be} /{ }^{9} \mathrm{Be}$ values of $1.447 \times 10^{-15}$ and $2.624 \times 10^{-15}$, compared to samples ranging from $1.476 \times 10^{-14}$ to $5.286 \times 10^{-14}$. ${ }^{10} \mathrm{Be}$ concentrations in each sample were calculated from measured ratios and are reported in Table 2.

\subsection{Inferring long-term denudation rates from ${ }^{10} \mathrm{Be}_{\mathrm{qtz}}$}

The widely used approach to determining denudation rates from ${ }^{10} \mathrm{Be}_{\mathrm{qtz}}$ (e.g., von Blanckenburg, 2006; Dunai, 2010; Granger and Riebe, 2007; Granger et al., 2013) assumes that erosion occurs at steady state from the Earth's surface, such that (see the Appendix A1 for more details)

$C_{\mathrm{sed}}=\sum_{i} \frac{P_{i}(0)}{\lambda+\rho \varepsilon / \Lambda_{i}}$,

where $C_{\text {sed }}$ is the measured ${ }^{10} \mathrm{Be}$ concentration in river sediment quartz, $i$ denotes each cosmogenic production pathway of ${ }^{10} \mathrm{Be}, P_{i}(0)$ is the production via pathway $i$ at the surface (i.e., where depth $z=0$ ), $\lambda$ is the ${ }^{10} \mathrm{Be}$ decay constant, $\rho$ is the density of eroding rock (we use $\rho=2.6 \mathrm{~g} \mathrm{~cm}^{-3}$ ), $\varepsilon$ is the steady-state denudation rate, and $\Lambda_{i}$ is the attenuation length associated with production pathway $i$. We use two terms in Eq. (1) - one term for production by neutron spallation and another for muonic production. For neutrons, we use $\Lambda_{n}=160 \mathrm{~g} \mathrm{~cm}^{-2}$ (a widely adopted value; cf. Goethals et al., 2009) and $P_{n}(0)$ calculated for the mean latitude, longitude, and elevation of each catchment based on scaling of a sea level high-latitude spallation production rate of 4.49 at $\mathrm{g}^{-1} \mathrm{yr}^{-1}$ (Stone, 2000; using code of Balco et al., 2008). For muons, we use $\Lambda_{m}=4200 \mathrm{~g} \mathrm{~cm}^{-2}$ (the median value from the compilation of Braucher et al., 2013) and $P_{m}(0)$ calculated for the mean elevation of each catchment based on scaling of a sea level high-latitude muonic production rate of 0.028 at $\mathrm{g}^{-1} \mathrm{yr}^{-1}$ (Braucher et al., 2011, 2013).
Characteristic surface production rates for each catchment were determined for the elevation and latitude of each pixel in a $30 \mathrm{~m}$ catchment DEM, with neutron production rates at each pixel corrected for topographic shielding based on a skyline estimation (using an adapted version of the code from http://depts.washington.edu/cosmolab/shielding.m). Median corrected production rates and median shielding values are reported for each catchment in Table 3. The corrected production rates calculated by this method are similar to those for the mean catchment elevation and latitude (cf. von Blanckenburg, 2006).

Steady-state denudation rate is found by inverting Eq. (1) for $\varepsilon$ (see Table 3 for the Likhu sample results). Uncertainties in erosion are reported 16th and 84th percentiles (i.e., $68 \%$ confidence interval) of the Monte Carlo distributions derived from repeating the inversion taking into account $1 \sigma$ measurement error on $C_{\text {sed }}$ (Table 1 ), uncertainties of $10 \mathrm{~g} \mathrm{~cm}^{-2}$ and $500 \mathrm{~g} \mathrm{~cm}^{-2}$ on $\Lambda_{n}$ and $\Lambda_{m}$ respectively, and the $68 \%$ confidence interval of the distribution of calculated $P_{m}(0)$ and $P_{n}(0)$ within each catchment. This Monte Carlo approach allows for estimating what are found to be non-normal, asymmetric uncertainties on $\varepsilon$.

\subsection{Additional data}

Additional data from other catchments in Nepal were assembled from the literature to provide wider context for the measurements from the Likhu Khola reported here. In all cases, calculated denudation rates (in $\mathrm{mm} \mathrm{yr}^{-1}$ average surface lowering, as reported in the data tables in this study) were converted to erosional fluxes (in $\mathrm{t} \mathrm{km}^{-2} \mathrm{yr}^{-1}$ ) for comparison to sediment yields. Mass conversion was done based on density of $2.6 \mathrm{~g} \mathrm{~cm}^{-3}$, because rock density controls the amount of sediment production over depths measured by ${ }^{10} \mathrm{Be}_{\mathrm{qtz}} \mathrm{de}-$ nudation rates. The denudation rates and fluxes calculated from ${ }^{10} \mathrm{Be}_{\mathrm{qtz}}$ reflect long-term losses via both physical erosion and chemical weathering, as discussed in greater detail below.

\section{Erosion rates}

\subsection{Long-term background rates from the Likhu Khola}

Background denudation rates (Table 3 ) inferred from ${ }^{10} \mathrm{Be}_{\mathrm{qtz}}$ using Eq. (1) range from $702+156 /-130$ to $1066+$ $364 /-234 \mathrm{mmyr}^{-1}$ (median $\pm 68 \%$ confidence interval from Monte Carlo error propagation) in the headwater Bore and Chinnya catchments, which are only minimally affected by agricultural land use. At these erosion rates, ${ }^{10} \mathrm{Be}_{\mathrm{qtz}}$ integrates over timescales of $\sim 1600-2500$ years. The inferred erosion rates are identical for all size fractions of the river sediment from the Chinnya catchment. In the Bore catchment, rates in the $0.25-0.71 \mathrm{~mm}$ and $0.71-2 \mathrm{~mm}$ size fractions of river sediment were identical, while best estimate rates in the $2-4 \mathrm{~mm}$ fraction were $50 \%$ higher but not quan- 
Table 2. ${ }^{10} \mathrm{Be}_{\mathrm{qtz}}$ in river sediment from the Likhu Khola Basin in the Nepal Middle Hills.

\begin{tabular}{|c|c|c|c|c|c|c|c|}
\hline Sample & Name & $\begin{array}{l}\text { Date } \\
\text { collected }\end{array}$ & $\begin{array}{l}\text { Sample } \\
\text { lat/long }\end{array}$ & $\begin{array}{l}\text { Sample } \\
\text { elevation } \\
(\mathrm{m})\end{array}$ & $\begin{array}{l}\text { Mean } \\
\text { catchment } \\
\text { elevation* (m) }\end{array}$ & $\begin{array}{l}\text { Grain size } \\
(\mathrm{mm})\end{array}$ & $\begin{array}{l}{ }^{10} \mathrm{Be}_{\mathrm{qtz}} \\
\left(10^{3} \text { at } \mathrm{g}^{-1} \pm 1 \sigma\right)\end{array}$ \\
\hline CT71 & Likhu Khola & 9 May 2002 & $\begin{array}{l}27.8975^{\circ} \mathrm{N} \\
85.2212^{\circ} \mathrm{E}\end{array}$ & 533 & 1366 & $0.25-0.71$ & $13.51 \pm 3.13$ \\
\hline CT84 & Chinnya Khola & 16 May 2002 & $\begin{array}{l}27.8413^{\circ} \mathrm{N} \\
85.3072^{\circ} \mathrm{E}\end{array}$ & 960 & 1308 & $\begin{array}{l}0.25-0.71 \\
0.71-2 \\
2-4\end{array}$ & $\begin{array}{l}22.85 \pm 2.79 \\
22.33 \pm 1.91 \\
21.87 \pm 5.40\end{array}$ \\
\hline CT85 & Bore Khola & 16 May 2002 & $\begin{array}{l}27.8411^{\circ} \mathrm{N} \\
85.3076^{\circ} \mathrm{E}\end{array}$ & 962 & 1646 & $\begin{array}{l}0.25-0.71 \\
0.71-2 \\
2-4\end{array}$ & $\begin{array}{l}29.73 \pm 2.51 \\
29.10 \pm 3.80 \\
19.60 \pm 3.56\end{array}$ \\
\hline
\end{tabular}

* Mean elevation calculated from $30 \mathrm{~m}$ DEM, with catchment areas delineated using a flow-routing algorithm in Grass GIS.

Table 3. Cosmogenic production rates and inferred denudation rates for Likhu Khola samples.

\begin{tabular}{|c|c|c|c|c|c|c|c|c|c|}
\hline Sample & Catchment & $\begin{array}{l}\text { Grain } \\
\text { size } \\
(\mathrm{mm})\end{array}$ & $\begin{array}{l}\text { Topo. } \\
\text { shielding }\end{array}$ & $\begin{array}{l}P_{n}(0)^{\mathrm{b}} \\
\left(\mathrm{at} \mathrm{g}^{-1}\right. \\
\left.\mathrm{yr}^{-1}\right)\end{array}$ & $\begin{array}{r}P_{m}(0)^{\mathrm{c}} \\
\left(\text { at g }^{-1}\right. \\
\left.\mathrm{yr}^{-1}\right)\end{array}$ & $\begin{array}{l}\text { Steady-state denudation } \\
\text { rate }^{\mathrm{d}}\left(\mathrm{mm} \mathrm{yr}^{-1}\right)\end{array}$ & $\begin{array}{l}\text { Equivalent erosion } \\
\left.\text { flux } \mathrm{t} \mathrm{km}^{-2} \mathrm{yr}^{-1}\right)\end{array}$ & $\begin{array}{c}\text { Averaging } \\
\text { timescale } \\
(\mathrm{yr})\end{array}$ & $\begin{array}{c}\text { Inferred soil } \\
\text { production rate } \\
\left(\mathrm{mm} \mathrm{yr}^{-1}\right)\end{array}$ \\
\hline CT71 & Likhu Khola & $0.25-0.71$ & 0.973 & 9.37 & 0.052 & $\mathbf{0 . 4 9}+0.23 /-0.18$ & $1274+598 /-468$ & 1430 & $\sim 0.35$ \\
\hline СТ84 & $\begin{array}{l}\text { Chinnya } \\
\text { Khola }\end{array}$ & $\begin{array}{l}0.25-0.71 \\
0.71-2 \\
2-4\end{array}$ & 0.943 & 8.83 & 0.051 & $\begin{array}{l}\mathbf{0 . 2 7}+0.06 /-0.05 \\
\mathbf{0 . 2 8}+0.05 /-0.05 \\
\mathbf{0 . 2 8}+0.11 /-0.06\end{array}$ & $\begin{array}{l}702+156 /-130 \\
728+130 /-130 \\
728+286 /-156\end{array}$ & $\begin{array}{l}2570 \\
2520 \\
2460\end{array}$ & $\sim 0.27$ \\
\hline CT85 & Bore Khola & $\begin{array}{l}0.25-0.71 \\
0.71-2 \\
2-4\end{array}$ & 0.959 & 11.87 & 0.060 & $\begin{array}{l}\mathbf{0 . 2 7}+0.06 /-0.06 \\
\mathbf{0 . 2 8}+0.07 /-0.06 \\
\mathbf{0 . 4 1}+0.14 /-0.09\end{array}$ & $\begin{array}{c}728+156 /-156 \\
728+182 /-156 \\
1066+364 /-234\end{array}$ & $\begin{array}{l}2510 \\
2460 \\
1660\end{array}$ & $\sim 0.26$ \\
\hline
\end{tabular}

a Correction ratio for topographic shielding of ${ }^{10} \mathrm{Be}$ production, used in determining $P_{n}(0)$

${ }^{\mathrm{b}}$ Catchment-average ${ }^{10} \mathrm{Be}$ production rate in quartz at $z=0$ by neutron spallation (calculated based on Balco et al., 2008).

${ }^{\mathrm{c}}$ Catchment-average ${ }^{10} \mathrm{Be}$ production rate in quartz at $z=0$ by muons (calculated based on Braucher et al., 2013).

${ }^{\mathrm{d}}$ Denudation rate from Eq. (1) for steady state; errors reflect 16th and 84th percentiles of Monte Carlo distributions $(n=10000)$. Bold values are medians of the distributions, and are equivalent to direct solution of Eq. (1) for best estimates of parameter values.

${ }^{\mathrm{e}}$ Calculated for density of eroding rock of $2.6 \mathrm{~g} \mathrm{~cm}^{-3}$.

${ }^{\mathrm{f}}$ Uncertainties not reported on soil production rates because they were not estimated for landslide fluxes.

titatively distinguishable within analytical error. There is no statistically significant difference between rates in the Bore and Chinnya. Calculated steady-state denudation rates at the Likhu main stem site were $1274+598 /-468 \mathrm{tkm}^{-2} \mathrm{yr}^{-1}$, higher than in either of the smaller subcatchments for the equivalent grain size range $(0.25-0.71 \mathrm{~mm})$ of river sediment.

\subsection{Anthropogenically perturbed rates from the Likhu Khola}

Suspended sediment yields in the Bore Khola, measured at the outlet of the larger catchment that comprises both the Bore and Chinnya headwaters and includes significant ( $40 \%)$ agricultural area (Fig. 2; Table 1), totaled 341$1527 \mathrm{t} \mathrm{km}^{-2}$ during the monsoon season of 1992 (Table 4; from Brasington and Richards, 2000). The wide range in these estimates is attributable to the different methods of calibrating the field measurements (Brasington and Richards,
2000). This range provides a reasonable estimate of the total annual sediment yield, since over $90 \%$ of rainfall and the majority of sediment removal takes place during the monsoon season (Gerrard and Gardner, 1999). However, measured suspended sediment fluxes in this system are probably sensitive to the runoff in any given year of observation (Brasington and Richards, 2000).

Plot studies from bari terraces yielded soil loss rates from 270 to $1290 \mathrm{tkm}^{-2}$ during the monsoon seasons in 1992 and 1993 (Gardner and Gerrard, 2003), with a median and $68 \%$ confidence interval of $460+469 /-138 \mathrm{tkm}^{-2}(n=$ 14). Soil loss rates on grassland and natural forest were lower, $\sim 50 \mathrm{tkm}^{-2}$, but rates on degraded forest were substantially higher, $\sim 1000-2000 \mathrm{t} \mathrm{km}^{-2}$ (Gardner and Gerrard, 2001, 2002).

Gerrard and Gardner (1999, 2002) estimated an average denudation rate from mass wasting equivalent to $406 \mathrm{t} \mathrm{km}^{-2} \mathrm{yr}^{-1}$ for the Likhu Basin as a whole (note their 1999 paper reports rates in $\mathrm{mm} \mathrm{yr}^{-1}$ that are 10 times too 
high due to a conversion error, but this is corrected in the 2002 paper). They measured lower rates $\left(\sim 57 \mathrm{tkm}^{-2} \mathrm{yr}^{-1}\right)$ for the Bore subcatchment and suggested that this lower value is more representative of the southern slopes of the Likhu, based on aerial images (Gerrard and Gardner, 1999).

\subsection{Comparative data from Middle Hills region of Nepal}

Other than our study in the Likhu, we are not aware of any other data pairing short-term (annual to decadal) erosion rates with ${ }^{10} \mathrm{Be}_{\mathrm{qtz}}$-derived long-term denudation rates where both data have been collected at the same site in the agricultural Himalayan Middle Hills. However, there are additional erosion rate data from a variety of other sites in Nepal (see Fig. 1 and discussion below).

Previously reported ${ }^{10} \mathrm{Be}_{\mathrm{qtz}}$-derived denudation rates from other small catchments in Nepal are equivalent to erosion fluxes ranging from $260 \pm 26$ to $4706 \pm 1274 \mathrm{tkm}^{-2} \mathrm{yr}^{-1}$ (Godard et al., 2014; Wobus et al., 2005; see Supplement Table S1). The large range in observed rates has been attributed to variable tectonic position, with significantly higher denudation rates in the more rapidly uplifting High Himalaya (Godard et al., 2014; Wobus et al., 2005). Data that are comparative to the region of the Likhu Khola are those restricted to catchments south of the MCT, and south of the physiographic and denudational transition that may demarcate blind thrusting (Wobus et al., 2005). The data from these catchments $\left(n=20\right.$, catchment area $\left.=4-110 \mathrm{~km}^{2}\right)$ yield a median denudation rate of $494+565 /-182 \mathrm{tkm}^{-2} \mathrm{yr}^{-1}(68 \%$ confidence interval). This value is similar to the ${ }^{10} \mathrm{Be}_{\mathrm{qtz}}{ }^{-}$ derived denudation rates we have measured in the Bore and Chinnya. These rates from Nepal are also similar to those observed in the lower-elevation regions of the Garwhal Himalaya in India (Scherler et al., 2014). The rates we measure for the Likhu main stem are notably higher, and approach rates found in the High Himalaya. The values discussed here are all previously published denudation rates, and are not reprocessed with the same method as used in this study for calculating denudation rate from ${ }^{10} \mathrm{Be}$ concentrations. Comparison of ${ }^{10} \mathrm{Be}_{\mathrm{qtz}}$-derived rates between different studies should be interpreted in the context that reported rates were not all calculated with the same ${ }^{10} \mathrm{Be}_{\mathrm{qtz}}$ production scheme.

Additional data on short-term soil loss from agricultural lands in Nepal provide widely varying erosion rates, with plot study data ranging from $<10$ to $>10000 \mathrm{tkm}^{-2} \mathrm{yr}^{-1}$ (as compiled by Chalise and Khanal, 1997; Jha and Paudel, 2010). This variability may partly reflect different land use practices at the different sites that have been studied. Such variation is consistent with observations in the Likhu Khola of varying plot-level soil loss, depending on the type of land use.

The data most immediately comparable to the river sediment ${ }^{10} \mathrm{Be}_{\mathrm{qtz}}$ denudation rates are river sediment fluxes that integrate across multiple land use types. Many of the rivers monitored for suspended sediment in Nepal have very large catchment areas that drain significant High Himalayan regions (e.g., data in Andermann et al., 2012), while others drain significant portions of the lowland Terai floodplain. Since these different physiographic regimes may be characterized by considerably different background erosion rates (Wobus et al., 2005; Godard et al., 2014; see Fig. 1), the sediment yields from the large river basins do not provide a robust comparison to the long-term rates determined specifically for the Middle Hills, as in this study. Considering only sediment yields from rivers with catchment areas restricted to the Middle Hills, suspended sediment fluxes range from 173.5 to $3700 \mathrm{tkm}^{-2} \mathrm{yr}^{-1}$ (as reported by Andermann et al., 2012; Bajracharya et al., 2004; Chalise and Khanal, 1997; see Table S2). The distribution of rates is positively skewed, with a median value ( $\pm 68 \%$ confidence interval; $n=8)$ of $892+1074 /-458 \mathrm{tkm}^{-2} \mathrm{yr}^{-1}$. This value should be interpreted with caution since sediment yields calculated by Andermann et al. (2012) in some cases yield significantly different values compared to the estimates from Chalise and Khanal (1997), for example lower by 2 times or more at some gauging stations (Table S2; Fig. S1 in the Supplement). Important methodological details such as the length of record and the number of measurements were not reported by Chalise and Khanal (1997), so it is difficult to identify reasons for these differences, and the Andermann et al. (2012) data set does not include enough basins that drain exclusively the Middle Hills to allow an independent estimate.

\subsection{Comparative data from other Himalayan regions}

In addition to the variety of data from Middle Hills locations discussed above, data sets from large Himalayan rivers and from the Khudi Khola catchment, which has a predominantly High Himalayan catchment area and more limited agricultural activity, allow direct comparison of sediment fluxes and ${ }^{10} \mathrm{Be}_{\mathrm{qtz}}$-derived denudation rates more widely across Nepal. These comparisons are discussed in Sect. 5.3, below.

\section{Discussion}

\subsection{Spatial variability in erosion rates in the Likhu Khola}

Rates of long-term erosion inferred from ${ }^{10} \mathrm{Be}_{\mathrm{qtz}}$ are similar across different grain sizes for the Bore and Chinnya, both of which are on the southern slopes of the Likhu Valley. In contrast, the ${ }^{10} \mathrm{Be}_{\mathrm{qtz}}$-derived erosion rate for the Likhu main stem is significantly higher. In previous work, mass wasting losses were also found to be higher in the Likhu Valley as a whole, when compared to the Bore, and rates were particularly identified as being higher on the northern slopes of the Likhu Valley (Gerrard and Gardner, 1999, 2002). Based on 1992-1993 precipitation measurements at rain gauges distributed throughout the Likhu Khola, there is no evidence for systematically greater rainfall on the northern slopes (Gardner and Jenkins, 1995). There are multiple possible other ex- 
planations for differences in denudation rate between southern and northern slopes of the Likhu:

1. Differences in ${ }^{10} \mathrm{Be}_{\mathrm{qtz}}$-derived erosion rates might result from artifacts due to reworking of cosmogenically shielded alluvial by the Likhu main stem (cf. Wittman and von Blanckenburg, 2009), or from the stochastic supply of sediment with variable ${ }^{10} \mathrm{Be}$ concentrations to this site, for example due to supply from different tributaries (cf. Lupker et al., 2012) or from mass wasting sources (cf. Niemi et al., 2005; West et al., 2014; Puchol et al., 2014). These explanations would not, on their own, also explain differences in mass wasting rates between northern and southern slopes.

2. The different rates of mass wasting might be attributable to differences in land use effects, with more land degradation on northern slopes. This idea was suggested by Gerrard and Gardner $(1999,2002)$ and is evident in the soil erosion modeling analysis of Shrestha et al. (2004). If land degradation is hastening mass wasting on northern slopes, it might contribute to the lower ${ }^{10} \mathrm{Be}_{\mathrm{qtz}}$ in the Likhu main stem, explaining both sets of observations.

3. Alternatively, the observed difference may be related to the presence of the Likhu Fault that runs east-west through the middle of the valley (Fig. 1). If this fault accommodates deformation, for example associated with the Main Central Thrust (MCT), then higher tectonically driven denudation rates might be expected on the northern slopes (cf. Godard et al., 2014; Wobus et al., 2005). This might be expected to increase both the observed mass wasting rates and the inferred long-term denudation rates. The ${ }^{10} \mathrm{Be}_{\mathrm{qtz}}$ denudation rates in the Bore and Chinnya are similar to other denudation rates in the Middle Hills of Nepal, while the rates for the Likhu Khola as a whole approach the higher rates observed in association with more rapid tectonic uplift in the Nepal High Himalaya (Godard et al., 2014; Wobus et al., 2005). The northern slopes of the Likhu do not have obviously different relief structure (e.g., river channel steepness), as might be expected for a different uplift and erosion regime (Godard et al., 2014; Scherler et al., 2014). However, nonlinearity in such relationships mean that differences in topographic parameters associated with the $\sim 2$-fold difference in denudation rate might not be easy to identify across the Likhu.

\subsection{Short-term versus long-term erosion rates in the Likhu Khola}

\subsubsection{Comparative rates}

To first order, the ${ }^{10} \mathrm{Be}_{\mathrm{qtz}}$-derived, natural background erosion rates measured for the headwater Bore and Chinnya are similar to present-day sediment fluxes, lying in the middle of the range of river suspended sediment flux estimates for the Bore main stem (Table 4, Fig. 4a). The long-term denudation rates are also indistinguishable from the soil loss rates from plots on well-maintained bari terraces. In contrast, soil loss rates from degraded lands are higher (Table 4). Terracing is intended to reduce soil erosion (cf. Gardner and Gerrard, 2003; Smadja, 1992; Tiwari et al., 2009), so a lower rate of sediment losses from terraces is expected. Rapid soil loss from degraded lands has also been widely observed (e.g., Burton et al., 1989; Gardner and Jenkins, 1995; Merz, 2004); the comparison presented here confirms that this anthropogenically associated loss exceeds the rate of long-term background erosion in the Likhu.

The similarity of long-term and present-day erosion rates that we observe in the agricultural Likhu Khola contrasts with the significantly higher present-day versus long-term fluxes measured in agricultural catchments in Sri Lanka and Ecuador (Fig. 4a). Even the difference between the longterm erosion rates in the Likhu and the soil loss rates on degraded lands ( $\sim 3$-fold increase) is lower than the $>10$-fold erosional flux increase observed in some of the Sri Lanka and Ecuador catchments when comparing short- and longterm rates. Vanacker et al. (2014) observed little difference between short- and long-term erosion rates in agricultural catchments of the Baetic Cordillera of Spain and suggested that the difference between present-day vegetation cover $(V)$ and natural vegetation cover $\left(V_{\text {ref }}\right)$ exerts a primary control on the extent of agricultural enhancement of erosion. Compared to the data from Spain and Ecuador, the data from the Likhu Khola point to relatively lower agricultural enhancement of erosion for a given change in vegetation cover (Fig. 4b).

Land use is not the only factor that may differ between erosion rates derived from ${ }^{10} \mathrm{Be}_{\mathrm{qtz}}$ and those determined from other measurements such as sediment fluxes. Erosion rates often vary as a function of spatial scale (Covault et al., 2013; de Vente et al., 2007; Milliman and Syvitski, 1992; Saunders and Young, 1983; Bierman and Nichols, 2004), potentially complicating comparison of plot-level soil losses with catchment-wide denudation rates. The ${ }^{10} \mathrm{Be}_{\mathrm{qtz}}$-based denudation rates and river suspended sediment fluxes for the Bore are at comparable scale, but the results from terrace plots are not. Other relevant factors include (i) differences between measuring suspended sediment fluxes compared to total denudation rate; (ii) whether sediment fluxes over observed timescales are representative; and (iii) whether there are biases in the ${ }^{10} \mathrm{Be}_{\mathrm{qtz}}$-based denudation rates, potentially resulting from non-steady-state effects. These issues are discussed in turn in the following subsections.

\subsubsection{Dissolved and bedload contributions to total denudation}

Suspended sediment flux measurements do not include either dissolved mass losses or particulate transport in bedload, 

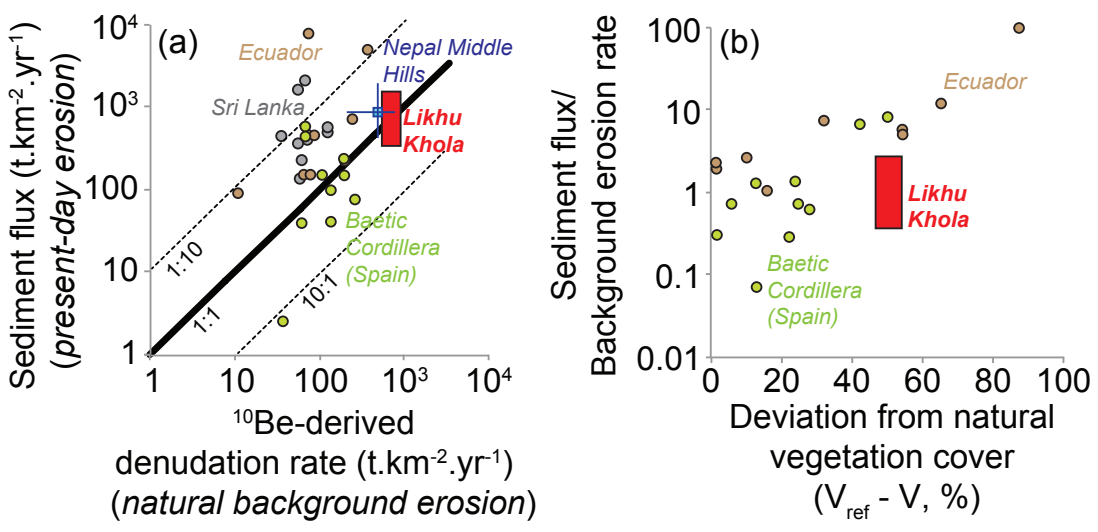

Figure 4. (a) Comparison of short-term erosion rates from sediment fluxes and long-term denudation rates from ${ }^{10} \mathrm{Be}$ concentrations in quartz from river sediment, from mountain catchments in different settings all with significant agricultural land use. The red box shows range of ${ }^{10} \mathrm{Be}_{\mathrm{qtz}}$-derived rates for Bore Khola determined in this study, compared to sediment fluxes from the Bore in 1992 (Brasington and Richards, 2001). The light-blue point shows the median $\pm 68 \%$ confidence interval of the data set on ${ }^{10} \mathrm{Be}_{\mathrm{qtz}}$ denudation rate and sediment flux from other catchments in the Nepal Middle Hills (note that these data are not from paired catchments and that the sediment fluxes are highly uncertain; see text and Tables S1, S2). The Nepal data indicate little increase in present-day sediment fluxes above background denudation rates, in contrast to the large increases in present-day rates observed in many catchments in Sri Lanka (gray points; Hewawasam et al., 2004) and Ecuador (brown points; Vanackar et al., 2007), but similar to many agricultural catchments in the Baetic Cordillera of Spain. (b) Comparison of the present-day enhancement of erosion rate to the extent of anthropogenic disturbance of native vegetation. The data from the Likhu Khola indicate less enhancement of erosion for a given change in vegetation cover compared to catchments in Spain and Ecuador.

both of which are part of the total denudation flux captured by ${ }^{10} \mathrm{Be}_{\mathrm{qtz}}$. In the Bore and Chinnya, dissolved fluxes are low relative to the total denudation (dissolved fluxes are less than $\sim 5-10 \%$ of the total denudation flux; West et al., 2002), so this flux is not expected to be a major factor in our analysis. Bedload transport may comprise a significant portion of the total denudation flux in mountain systems. Measurements in the High Himalaya of the Marsyandi River basin suggest bedload may account for as much as $\sim 35 \%$ of the total denudation flux (Pratt-Sitaula et al., 2007), such that total annual to decadal erosion rates may be $\sim 50 \%$ higher than suspended sediment fluxes. If the sediment fluxes measured in the Bore underestimate total present-day erosion by approximately this magnitude, actual total present-day rates may be slightly higher than long-term rates (as in Fig. 4a), but the differences would still be lower than the $\sim 10$-fold increases in present-day erosion over the long term observed elsewhere. Moreover, it is unclear whether erosion in the Nepal Middle Hills is in fact characterized by as much as $35 \%$ bedload transport, as measured in the High Himalaya. Bedload transport may be less important in other mountainous environments (Lane and Borland, 1951), and Hewawasam et al. (2003) observed similarity in total sediment delivery to reservoirs (which includes bedload material) and suspended sediment fluxes in the tropical highlands of Sri Lanka, suggesting relatively low bedload transport there.

\subsubsection{How representative are the short-term flux measurements?}

The short-term data on stream sediment flux and soil loss from plots in the Likhu were all collected from a short time window (over 1-3 years) in the early 1990s. Erosion over longer (e.g., decadal or even centennial) timescales is most relevant for soil degradation, reservoir sedimentation, and similar environmental concerns. Rainfall and runoff were slightly lower than the longer-term average during the observational period in the 1990s in the Likhu, so the measured fluxes may underestimate actual erosion rates over decadal timescales (Brasington and Richards, 2000). Moreover, short-term measurements can inherently underestimate longer-term erosion rates if they miss episodic highmagnitude, low-frequency events (e.g., Covault et al., 2013; Kirchner et al., 2001). The similarity between short- and long-term rates that we observe might be an artifact of measurement if decadal sediment fluxes are actually significantly elevated relative to the long-term rates but measured sediment fluxes were underestimated during our observational period. Sediment fluxes have been measured over a much longer period of time in the nearby Trisuli River (Fig. 1), with calculated sediment yields of $970 \mathrm{t} \mathrm{km}^{-2} \mathrm{yr}^{-1}$ (Chalise and Khanal, 1997; unknown number of samples and time interval) and $542 \mathrm{t} \mathrm{km}^{-2} \mathrm{yr}^{-1}$ (Andermann et al., 2012; based on 665 measurements between 1973 and 1979). These values are similar to the $341-1527 \mathrm{t} \mathrm{km}^{-2} \mathrm{yr}^{-1}$ observed in the Bore Khola (Table 3). The Trisuli Basin $\left(\sim 4500 \mathrm{~km}^{2}\right.$ area) covers a much larger area than the Likhu and includes signifi- 
Table 4. Summary of erosional fluxes measured in the Likhu Khola.

\begin{tabular}{|c|c|c|c|}
\hline Measurement & Source & Site & $\begin{array}{l}\text { Sediment flux } \\
\mathrm{t} \mathrm{km}^{-2} \mathrm{yr}^{-1}\end{array}$ \\
\hline $\begin{array}{l}\text { Suspended } \\
\text { sediment flux }\end{array}$ & $\begin{array}{l}\text { Brasington and } \\
\text { Richards (2001) }\end{array}$ & Bore Khola & $341-1527$ \\
\hline $\begin{array}{l}\text { Soil loss rate } \\
\text { from plots }\end{array}$ & $\begin{array}{l}\text { Gardner and Gerrard } \\
(2001,2003)\end{array}$ & $\begin{array}{l}\text { Irrigated terraces } \\
\text { Rainfed terraces } \\
\text { Grassland } \\
\text { Forest } \\
\text { Degraded forest }\end{array}$ & $\begin{array}{l}\text { n.a. } \\
460^{+469 /-138} \\
50 \\
50 \\
100-2000\end{array}$ \\
\hline $\begin{array}{l}\text { Mass wasting flux } \\
\text { by land use type }\end{array}$ & $\begin{array}{l}\text { Gerrard and Gardner } \\
(2002)\end{array}$ & $\begin{array}{l}\text { Irrigated terraces } \\
\text { Rainfed terraces } \\
\text { Grassland } \\
\text { Forest } \\
\text { Degraded forest } \\
\text { and scrubland }\end{array}$ & $\begin{array}{l}48 \\
364 \\
186 \\
80 \\
2395\end{array}$ \\
\hline $\begin{array}{l}\text { Mass wasting flux } \\
\text { by catchment }\end{array}$ & $\begin{array}{l}\text { Gerrard and Gardner } \\
(1999,2002)\end{array}$ & $\begin{array}{l}\text { Bore Khola } \\
\text { Likhu Khola } \\
\text { Likhu Khola* }\end{array}$ & $\begin{array}{l}57 \\
551 \\
406\end{array}$ \\
\hline $\begin{array}{l}\text { Flux from long- } \\
\text { term denudation }\end{array}$ & Table 3 & $\begin{array}{l}\text { Bore Khola } \\
\text { Likhu Khola }\end{array}$ & $\begin{array}{l}572-910 \\
806-1872\end{array}$ \\
\hline
\end{tabular}

cant portions of the High Himalaya, so comparing rates from these two catchments is not straightforward. The High Himalaya generally produce higher long-term background erosion rates than the Middle Hills (Gabet et al., 2008; Godard et al., 2014), so if anything we might expect the Trisuli erosion rates to be higher than in the Likhu over similar time windows. The similarity of the Trisuli sediment fluxes to those measured in the Likhu provides a first-order indication that the Likhu fluxes are not grossly underestimated.

\subsubsection{How representative are the background denudation estimates?}

The long-term, background denudation rates calculated from ${ }^{10} \mathrm{Be}_{\mathrm{qtz}}$ using Eq. (1) assume steady state, which may be perturbed in settings such as the Likhu over the long-term by mass wasting (e.g., Niemi et al., 2005; Puchol et al., 2014; West et al., 2014; Yanites et al., 2009), and in the short term by anthropogenic soil reworking (e.g., von Blanckenburg et al., 2004; Brown et al., 1998; Ferrier et al., 2005). We consider the importance of these non-steady-state processes for calculated rates in the Likhu by modeling the perturbation to ${ }^{10} \mathrm{Be}$ concentration-depth profiles (see details in Appendices A2 and A3). In brief summary:

- Observed mass wasting fluxes in the Bore and the Chinnya are low (Table 3), so we expect that landslide activity does not strongly bias our calculated steady-state denudation rates for these sites (see Appendix A2). This is supported by the lack of significant grain size dependency of ${ }^{10} \mathrm{Be}_{\mathrm{qtz}}$ for the Bore and Chinnya samples, since significant landslide contributions have been found to generate large grain size differences (e.g., Aguilar et al., 2014; Belmont et al., 2007; Brown et al., 1995; Puchol et al., 2014). Such grain size variations are not universally observed (Clapp et al., 2002; Kober et al., 2012; Safran et al., 2005), so this cannot be taken as absolute confirmation that landslides are unimportant, but the combination of low present-day landslide fluxes and similarity across grain sizes suggests mass wasting processes probably do not strongly bias our estimated rates.

- Landslide occurrence is greater in the Likhu main stem, and is high enough to theoretically introduce significant uncertainty in our calculations. The Likhu catchment area is sufficiently large $\left(>100 \mathrm{~km}^{2}\right)$ that it may be expected to effectively average mass wasting inputs that occur stochastically in time and space across the catchment area (cf. model predictions of Niemi et al., 2005; Yanites et al., 2009), although episodic events may bias denudation rates estimates to some extent even in large catchments (West et al., 2014). In any case, the denudation rates we infer for the Likhu main stem are presented only for wider context and are not the primary reference for comparison to present-day sediment yields. 
- Anthropogenic reworking of soils due to agricultural activity may influence long-term erosion rates calculated from cosmogenic nuclide concentrations. For example, if land use has led to the loss of upper soil horizons, thereby removing ${ }^{10} \mathrm{Be}$-enriched surface material, then lower ${ }^{10} \mathrm{Be}$ surfaces supplying sediment to the streams today may yield a higher inferred erosion rate than is characteristic of natural background rates (e.g., von Blanckenburg et al., 2004; Brown et al., 1998; Ferrier et al., 2005). The uncertainty introduced as a result of such land use effects depends on (i) the depth of agricultural reworking and (ii) the depth of natural background soil mixing (see Appendix A3). We anticipate that the depth of reworking is not significantly greater than the depth of the mixed layer, since Likhu soils are on steep slopes and typically in the range of $0.5-2 \mathrm{~m}$ thickness. In this case, agricultural reworking would have no significant influence on denudation rates calculated from ${ }^{10} \mathrm{Be}_{\mathrm{qtz}}$ (Granger and Riebe, 2007). However, if the depth of reworking exceeded the mixing depth by $\sim 0.5 \mathrm{~m}$, for example via rill formation (e.g., von Blanckenburg et al., 2004), we estimate that the actual long-term denudation rates could be as much as $\sim 50 \%$ lower than those we infer from Eq. (1). For the headwater Bore and the Chinnya samples, which provide the reference for comparison to the short-term erosion rates, agricultural reworking is expected to be minimal since the upstream areas are predominantly forested (Fig. 3; Table 1).

Non-steady-state effects may also arise in river systems due to stochastic variability in sourcing of sediment, as suggested for large rivers draining the High Himalaya in central Nepal (Lupker et al., 2012). In particular, variation over time in input of sediment from source areas with distinct elevations and thus distinct ${ }^{10} \mathrm{Be}$ production rates may lead to variable ${ }^{10} \mathrm{Be}_{\mathrm{qtz}}$. The Bore and Chinnya are both low-order, headwater catchments, and these systems are not large enough to expect large changes in sources from different tributaries. Variable sourcing might be one explanation for the lower ${ }^{10} \mathrm{Be}_{\mathrm{qtz}}$ and thus higher inferred erosion rates in the Likhu main stem, as discussed above.

Although we cannot conclusively rule out some nonsteady-state bias in our calculation of background denudation rates, additional confidence in our inferred steady-state rates comes from comparison to long-term rates observed in other studies in the Nepal Middle Hills (Fig. 4; Table S1). Calculated steady-state denudation rates are similar across a wide range of catchments, despite differences in land use and catchment size; larger variability in steady-state rates from one catchment to another would be expected if ${ }^{10} \mathrm{Be}_{\mathrm{qtz}}{ }^{-}$ derived denudation rates were significantly influenced by land use or mass wasting in this environment. Moreover, the spatially consistent rates across the Nepal Middle Hills are also temporally consistent with long-term exhumation rates determined from thermochronology (Godard et al., 2014),

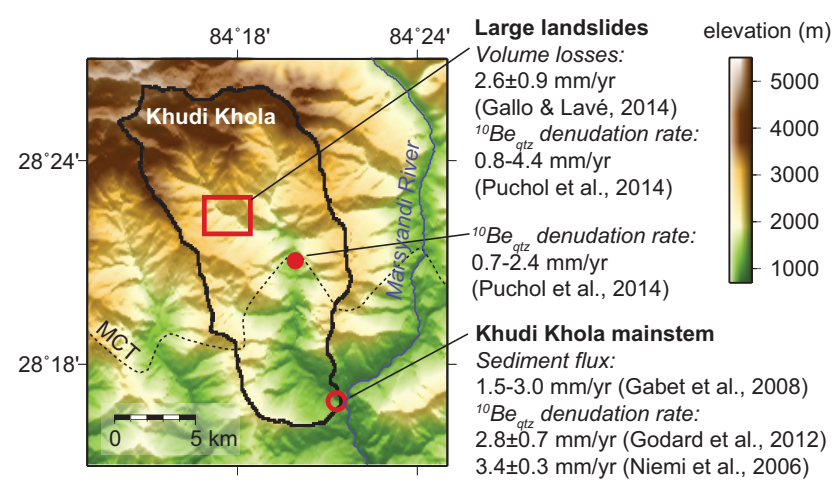

Figure 5. Khudi Khola catchment and reported erosion rates. Background elevation map from SRTM data at $90 \mathrm{~m}$ resolution; the solid black line is the Khudi catchment boundary and the dashed line (MCT) is the location of the Main Central Thrust from Puchol et al. (2014). Data are shown from a range of studies of both short- and long-term erosion rates in this catchment, which is eroding much more rapidly compared to the Likhu Khola (Fig. 3), is dominated by landslide erosion, and has little agricultural activity compared to the Likhu Khola.

suggesting that the inferred rates provide a reasonable estimate of actual long-term denudation.

\subsection{Comparison of short- vs. long-term rates across Nepal}

Additional short- and long-term erosion rate data from similar sites elsewhere in Nepal help provide more information to assess whether the short- versus long-term comparison in the Likhu data is representative. The significant spatial variability in erosion rates across Nepal (Fig. 1) and uncertainty in the wider Nepal sediment flux data (e.g., comparing data calculated by two different methods in Table S2; see Fig. S1) complicate direct comparison of erosion rates determined at other sites with those from the Likhu specifically. Moreover, none of the other short- and long-term data are paired from the same sites in the Middle Hills. However, considering the distribution of denudation rates across the Nepal Middle Hills, the picture is consistent with the Likhu data (range plotted for "Nepal Middle Hills" in Fig. 4). Overall, there may be a hint of a slight increase in short-term fluxes compared to long-term, and this may reflect a slight anthropogenic enhancement of erosion. But there is no evidence to support a large systematic difference, consistent with the similarity of short- and long-term erosion rates observed for the Likhu.

One other intensively studied site in Nepal, the Khudi Khola, also shows similar long-term denudation rates and sediment fluxes (Fig. 5). Both short- and long-term rates of erosion were measured at this site over a period of several years (Gabet et al., 2008; Niemi et al., 2005; Godard et al., 2012; Puchol et al., 2014). The Khudi catchment encompasses mostly areas north of the MCT with very high 
total denudation rates $\left(\sim 2-3 \mathrm{~mm} \mathrm{yr}^{-1}\right.$ for the catchment as a whole), and with little agricultural activity compared to the Likhu Khola. The high erosion rates in this catchment are thought to be largely dominated by landslides, and most of the decadal-timescale mass flux has been attributed to one large landslide source (Gallo and Lavé, 2014). The Khudi thus represents a significantly different geomorphic regime when compared to the Likhu, but again in this case the data do not suggest a dominant anthropogenic imprint on total erosional fluxes in the Nepal Himalaya (although such an imprint would probably be unexpected, given the high landslide rate and limited extent of agricultural activity in this catchment).

Similarly, the ${ }^{10} \mathrm{Be}_{\mathrm{qtz}}$ denudation rates and sediment fluxes from larger river basins in Nepal are generally similar in magnitude in most cases (e.g., when comparing ${ }^{10} \mathrm{Be}_{\mathrm{qtz}^{-}}$ derived rates from Lupker et al., 2012, and sediment fluxes from Andermann et al., 2012; see Fig. 1). These basins span across multiple physiographic regimes, which are characterized by distinct erosion rates (with typically higher erosion rates in the High Himalaya relative to the Middle Hills; Wobus et al., 2005; Godard et al., 2014). This heterogeneity means that it is not straightforward to isolate a single variable such as the effect of land use from these data, but the first-order similarity is consistent with the range of other observations including our results from the Likhu.

\subsection{Implications: sediment delivery, mass wasting, and soil production}

The implications of our results are that most of the sediment carried by the Likhu Khola, and by other similar rivers draining the Nepal Middle Hills, does not come from agricultural land degradation but rather from naturally high rates of landscape denudation. This observation suggests that soil management efforts should not necessarily be expected to dramatically reduce sediment delivery to downstream reservoirs and floodplains.

However, the lack of difference between short- and longterm erosion rates in Nepal cannot be taken on its own as evidence that land use is not affecting soil loss and hastening potential degradation of soil resources. This is because it is difficult to use catchment-scale fluxes to tease apart land use effects on soils specifically in cases where total erosion is dominated by gullies, landslides, debris flows, and analogous mass wasting sources. Where these processes are important, the observed catchment-scale rates (both short- and long-term) become dominated by the mass wasting supply, rather than by soil erosion, and small changes in erosion from soils become indistinguishable at the catchment scale. The comparison of short- and long-term rates then would not, on its own, reveal the extent to which agricultural land use degrades soil resources. The High Himalayan Khudi Khola (Fig. 5) represents an end-member case where most sediment is derived from mass wasting (cf. Niemi et al., 2005); the question is to what extent the same is true for the Likhu Khola and other Middle Hills catchments.

We can assess the relative importance of different erosion processes by mass balance. For a steady-state natural erosion system in the absence of agricultural activity, the erosional flux from long-term denudation $\left(F_{\mathrm{LT}}\right.$, derived from $\left.{ }^{10} \mathrm{Be}_{\mathrm{qtz}}\right)$ should be the sum of losses in dissolved form through chemical weathering, $F_{\text {DISS }}$, the denudation driven by mass wasting $\left(F_{\mathrm{MW}}\right)$, and the rate of incremental sediment loss from hillslopes, predominantly via diffusion-like sediment transport processes such as sheet erosion and rain splash erosion (collectively, $F_{\mathrm{DIFF}}$ ). If $F_{\mathrm{LT}}, F_{\mathrm{MW}}$, and $F_{\mathrm{DISS}}$ are known, and the erosional system is assumed to be at steady state at the catchment scale, then catchment-average rates of incremental sediment loss can then be estimated as

$F_{\mathrm{DIFF}}=F_{\mathrm{LT}}-F_{\mathrm{MW}}-F_{\mathrm{DISS}}$.

We can consider an analogous mass balance relation for soil production. The mobile solid material that makes up soil is produced via a range of biotic and abiotic processes on hillslopes (e.g., Heimsath et al., 1999). This soil material does not accumulate indefinitely but is removed by a combination of incremental, diffusive erosion and slope failures that remove soil from hillslopes $\left(F_{\mathrm{MW}, \mathrm{SOIL}}\right)$. Again assuming steady state, soil production $\left(\mathrm{F}_{\mathrm{SP}}\right)$ at the catchment scale should be described by

$F_{\mathrm{SP}}=F_{\mathrm{DIFF}}+F_{\mathrm{MW}, \mathrm{SOIL}}$.

Combining Eqs. (2 and 3) yields

$F_{\mathrm{SP}}=F_{\mathrm{LT}}+F_{\mathrm{MW}, \mathrm{SOIL}}-F_{\mathrm{MW}}-F_{\mathrm{DISS}}$

or

$F_{\mathrm{SP}}=F_{\mathrm{LT}}-F_{\mathrm{DISS}}-F_{\mathrm{MW}} \times\left(1-R_{\mathrm{MW}, \mathrm{SOIL}}\right)$,

where $R_{\mathrm{MW} \text {,SOIL }}$ is the proportion of the mass wasting flux constituted by mobile soil material.

For the Likhu Khola case, $F_{\mathrm{LT}}$ is known from the ${ }^{10} \mathrm{Be}_{\mathrm{qtz}}{ }^{-}$ based denudation rates (Table 3 ), and $F_{\text {DISS }}$ is considered to be a minor $(<\sim 5-10 \%)$ portion of the total budget (see discussion in Sect. 5.1, above). Lacking more robust constraints, we assume here that the present-day mass wasting rates measured in the Likhu Khola (Table 4) reflect background natural fluxes from mass wasting, providing a first-order estimate of $F_{\mathrm{MW}}$. Neither $R_{\mathrm{MW} \text {,SOIL }}$ nor $F_{\mathrm{MW}, \text { SOIL }}$ is known for this case, but we can calculate a minimum value for soil production by assuming that these values are zero, i.e., assuming that the mass wasting flux of soil material is negligible. For these assumptions, then from Eq. (4), resulting steady-state soil production rates (Fig. 6) would be $868 \pm 598 \mathrm{t} \mathrm{km}^{-2} \mathrm{yr}^{-1}$ for the Likhu catchment $\left(1274 \pm 598 \mathrm{t} \mathrm{km}^{-2} \mathrm{yr}^{-1}\right.$ total denudation minus $406 \mathrm{tkm}^{-2} \mathrm{yr}^{-1}$ mass wasting) and $671 \pm 156 \mathrm{tkm}^{-2} \mathrm{yr}^{-1}$ for the Bore subcatchment $\left(728 \pm 156 \mathrm{tkm}^{-2} \mathrm{yr}^{-1}\right.$ total 


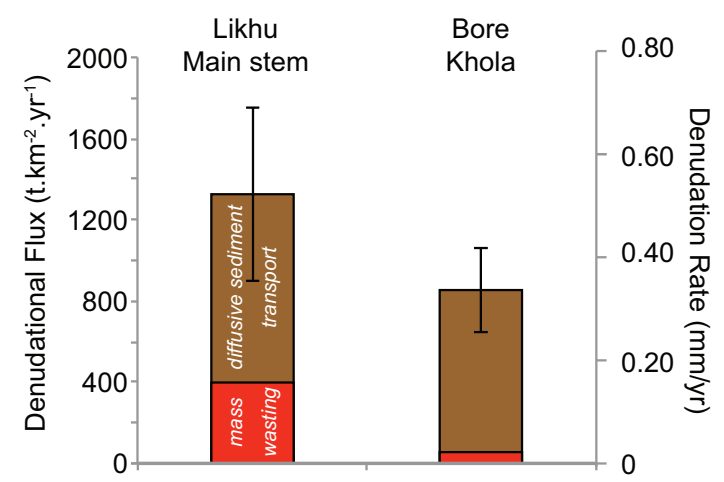

Figure 6. Contribution to catchment-wide denudation from mass wasting (determined from present-day measurements) and incremental sediment transport via diffusive-type processes (inferred as difference between mass wasting and total measured denudation rates; see text). Assuming present-day catchment-wide mass wasting fluxes represent the long-term average, then fluxes of diffusive sediment transport are similar for the Likhu main catchment and the Bore subcatchment. The diffusive fluxes provide a minimum estimate for soil production rates (see Sect. 5.4). Note that this partitioning yields a value for catchment-averaged soil production, and does not capture significant heterogeneity in soil production rates from one soil site to another within each catchment.

denudation and $57 \mathrm{tkm}^{-2} \mathrm{yr}^{-1}$ mass wasting). Interestingly, these soil production rates, equivalent to $\sim 0.25$ $0.35 \mathrm{~mm} \mathrm{yr}^{-1}$, are similar for both the Likhu and the Bore despite the very different rates of total denudation. Nonzero $F_{\mathrm{MW}, \text { SOIL }}$ would have little effect on the calculated soil production rate of the Bore, since the correction for mass wasting is small; the effect would be larger for the Likhu though it is possible that landslides in this catchment are dominated by non-soil material (i.e., with relatively low values of $F_{\mathrm{MW}, \mathrm{SOIL}}$ ).

There are several reasons that the estimates of $F_{\mathrm{MW}}$ used here may not accurately reflect long-term mass wasting rates, thus biasing our calculation of soil production rates. Presentday mass wasting estimates may be enhanced due to land use (Gerrard and Gardner, 2002), and if actual long-term mass wasting fluxes are lower, actual soil production rates would be higher. On the other hand, the episodic nature of landslides, particularly in a seismically active region (e.g., Keefer, 2004), may mean that the present-day mass wasting volume underestimates long-term rates by not capturing storm- or earthquake-triggered landslides, in which case soil production rates would be lower than our estimates. More comprehensive mapping of landslides over time could provide the foundation for more robustly determining denudation by mass wasting in the Middle Hills (cf. Hovius et al., 1997). However, this would require time series of high-resolution imagery, or other means of deriving landslide maps, that are not available in this study. We regard the mass wasting fluxes used here as an initial estimate allowing us to consider the balance of soil production as a proportion of to-

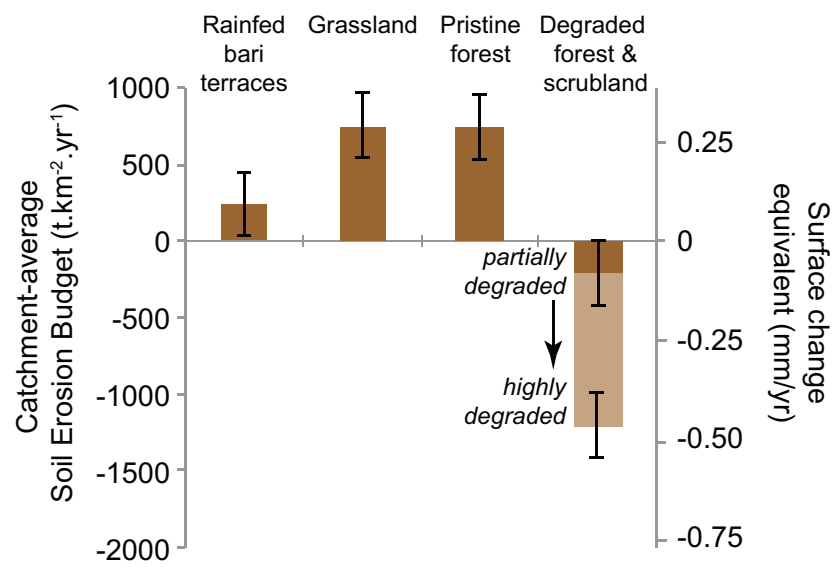

Figure 7. Net soil production/loss budget for different land use types in the Likhu Khola. Annual catchment-wide soil erosion budget based on inferred minimum soil production rates and measured soil losses from plots (Gardner and Gerrard, 2001, 2003). Site-specific soil production (and erosional loss) is likely to be highly variable, so the budget shown here will not apply to all soils. Nonetheless, the net budget illustrates that some land uses such as well-maintained terraces may have minimal effects on soil degradation, while other land uses may lead to highly unsustainable soil losses.

tal denudation in the Likhu. We emphasize that further work to better constrain the quantities in Eq. (5) - including direct measurement of soil production rates on hillslopes, longerterm information about landslide rates, and data on the proportion of the landslide flux from soil material - would help to provide better understanding.

Nonetheless, despite the uncertainties in our assumed values, it is interesting to consider the possible implications of our estimated soil production rates. These rates for the Likhu are relatively high in the global context but within the range observed for other mountain environments (Heimsath et al., 2012; Larsen et al., 2014). They suggest that the natural conversion of bedrock to soil is expected to yield relatively high sediment fluxes from hillslopes. Thus erosional losses from agricultural soils in the Middle Hills should not inherently be a cause for alarm on their own, although very high rates of soil loss, for example from degraded or abandoned lands, should be of concern (consistent with conclusions of Burton et al., 1989; Gardner and Jenkins, 1995; Merz, 2004). The inferred soil production rates can be compared to plot-scale soil losses to estimate the agricultural soil budget (Fig. 7). For degraded forests and scrubland, the deficit that results from anthropogenic modification is significant, in the range of $500-1500 \mathrm{t} \mathrm{km}^{-2} \mathrm{yr}^{-1}$, or $\sim 0.2-0.6 \mathrm{~mm} \mathrm{yr}^{-1}$ excess soil removal. This rate of removal could rapidly deplete soil resources (i.e., in comparison to A-horizon depths of $\sim 10$ $40 \mathrm{~cm}$ in the Likhu). Data on soil loss rates are not available for khet terraces, but for bari terraces, the resulting deficit from soil erosion is insignificant, suggesting that these 
terraces are effective at retaining soil. However, this result should be treated cautiously. For example, slumping of terrace risers is frequently observed (e.g., Gerrard and Gardner, 2000) and if such damage is not repaired it could lead to longer-term enhanced erosion. Moreover, modeling of soil erosion in the Likhu suggests that rainfed bari terrace soil losses may be significantly higher than the measured rates used in Fig. 7, while degraded forest losses may be lower (Shrestha, 1997). If bari terraces loss rates are in the range of $1000 \mathrm{~s}$ of $\mathrm{t} \mathrm{km}^{-2} \mathrm{yr}^{-1}$, as suggested by the model results, associated soil deficits would be much larger for this land use type than shown in Fig. 7.

Despite the many uncertainties, the conceptual framework illustrated in Figs. 6 and 7 may provide a useful context for considering how soil loss from agricultural land use compares to the long-term rates of soil production. One important consideration in such budgets is that the calculated soil production rates represent catchment-wide average values, and site-specific soil production rates are expected to vary significantly within the catchment, e.g., as a function of soil depth (Heimsath et al., 1997, 2012), which typically varies with topographic position. The deficits calculated for specific land use types provide a broad landscape perspective but are not expected to apply to all individual soil sites. It is also important to recognize that soil development and thickening is expected to take place in the short term where the soil erosion budget is positive under a given land use type, but over the long timescales of landscape evolution, these soils are likely to be disturbed by episodic losses, e.g., by slumping or other hillslope failure. Thus positive values in Fig. 7 will not necessarily lead to continued soil thickening across the catchment area over the long term.

\section{Conclusions}

Data on denudation rates from the agriculturally modified Middle Hills of Nepal show little measurable differences between short-term erosion rates, determined from river sediment fluxes and plot soil loss rates, compared to long-term "natural" background denudation rates, determined from cosmogenic ${ }^{10} \mathrm{Be}_{\mathrm{qtz}}$. The exception is on highly degraded lands where present-day soil losses are higher than background rates. The measured long-term cosmogenic rates are independent of the grain size analyzed for the catchments studied. The only significantly different long-term denudation rate is for the Likhu Khola main stem, which may be associated with enhanced denudation from activity on the Likhu Fault, but also may be influenced by sourcing effects, by the greater portion of agricultural land use in the catchment area, and/or by alluvial reworking of sediments with low ${ }^{10} \mathrm{Be}_{\mathrm{qtz}}$ by the larger river.

The similarity of short- and long-term rates in the Likhu Khola, and more widely in the Nepal Middle Hills, is in notable contrast to the large enhancement of short-term fluxes observed in other montane agricultural catchments. The Nepal data suggest that

1. much of the sediment carried by rivers out of the Nepal Middle Hills is derived from natural erosion, resulting from a combination of mass wasting and soil production from hillslopes, and does not result from soil degradation as a result of agriculture;

2. as suggested in previous research, well-maintained terraced agricultural practices in the Nepal Middle Hills appear to prevent very rapid acceleration of erosion that may take place under other mountain agriculture;

3. since overall erosion rates and rates of soil production are high, the loss of soil may not be unsustainable from well-maintained terraces, although less well-managed lands may be subject to rapid soil depletion relative to soil production, confirming previous work that has highlighted the risk of soil erosion on degraded lands in the Himalaya.

The sustainability of soil resources with respect to natural rates of hillslope soil production in the Himalayan Middle Hills depends on how lands are maintained. Our study supports the idea that poor land management indeed leads to unsustainable deficits of soil loss, while well-maintained terraces effectively mitigate such degradation. Additional data from longer time intervals that include higher magnitude erosional events would be important for confirming these observations. It is also important to recognize that the results from this study only concern the physical rates of soil loss and do not capture other potential aspects of environmental degradation associated with intensive agricultural land use, such as nutrient losses from soils and impacts on aquatic systems (e.g., Schreier et al., 2006). 
Appendix A: Effects of land use and mass wasting on denudation rates inferred from ${ }^{10} \mathrm{Be}_{\mathrm{qtz}}$

\section{A1 Conceptual framework: Basics of ${ }^{10}$ Be during active erosion}

The general equation for the accumulation of ${ }^{10} \mathrm{Be}$ as a function of time $t$ with depth $z$ below the Earth's surface (where the surface is defined as depth $z=0$ ) follows (Dunai, 2010; Granger and Riebe, 2007; Lal, 1991; see main text for definition of variables):

$C(z, t)=\sum_{i} \frac{P_{i}(0)}{\lambda+\rho \varepsilon / \Lambda_{i}} e^{-z \rho / \Lambda_{i}}\left(1-e^{-t\left(\lambda+\rho \varepsilon / \Lambda_{i}\right)}\right)$.

Over a sufficiently long period of time, the profile will reach a steady state between production of ${ }^{10} \mathrm{Be}$ and loss by erosion and decay, leading to a concentration-depth profile characterized by

$C(z)_{\text {steadystate }}=\sum_{i} \frac{P_{i}(0)}{\lambda+\rho \varepsilon / \Lambda_{i}} e^{-z \rho / \Lambda_{i}}$,

which reduces to the expression for steady-state composition of $C_{\text {sed }}$ (Eq. 1 of the main text) when taking $z=0$, i.e., assuming sediment is derived entirely by erosion from the surface. In this Appendix we consider the implications for the inferred denudation rates in the Likhu of (i) disturbing the steady-state profiles over the long-term by repeated mass wasting, and (ii) mobilizing sediment from below a steadystate surface, as may happen during agricultural reworking. We do this by modeling perturbations to the theoretical depth profiles described by Eqs. (A1 and A2).

Actual depth profiles on soil-mantled slopes typically depart from Eq. (A2) because of mixing within the mobile soil, for example due to bioturbation and downslope transport (e.g., Heimsath et al., 1997; Lal and Chen, 2005, 2006). Mixing does not affect the calculation of unperturbed steadystate denudation rate in Eq. (1) of the main text (see Granger and Riebe, 2007, for more on this problem), but mixing does affect the calculation of $\mathrm{C}(\mathrm{z})$ for a given profile. It is possible to account for the effect of mixing by calculating the concentration $C_{\text {mix }}$ within a mixed layer as (following Brown et al., 1995; Lal and Chen, 2005, 2006; Schaller et al., 2009):

$$
\begin{aligned}
& C_{\text {mix }}=\sum_{i} \frac{\Lambda_{i} \exp ?\left(-\rho z_{\text {mix }} / \Lambda_{i}\right)}{\Lambda_{i}-\rho z_{\text {mix }}} \frac{P_{i}(0)}{\lambda+\rho \varepsilon / \Lambda_{i}} \\
& \left(1-\mathrm{e}^{\left(-t\left(\lambda+\rho \varepsilon / \Lambda_{i}\right)\right)}\right)+\left(1-\frac{\Lambda_{i} \exp ?\left(-\rho z_{\text {mix }} / \Lambda_{i}\right)}{\Lambda_{i}-\rho z_{\text {mix }}}\right) \\
& \frac{P_{i}(0)}{\lambda \rho z_{\text {mix }} / \Lambda_{i}+\rho \varepsilon / \Lambda_{i}}\left(1-\mathrm{e}^{\left(-t\left(\lambda+\rho \varepsilon / \rho z_{\text {mix }}\right)\right)}\right),
\end{aligned}
$$

where $z_{\text {mix }}$ is the depth of the mixed layer of mobile soil and the other variables are as in Eqs. (1 and A1). For steady-state profiles, the exponential terms with time $t$ are assumed to reduce to zero, so

$$
\begin{aligned}
& C_{\text {mix }}=\sum_{i} \frac{\Lambda_{i} \exp ?\left(-\rho z_{\text {mix }} / \Lambda_{i}\right)}{\Lambda_{i}-\rho z_{\text {mix }}} \frac{P_{i}(0)}{\lambda+\rho \varepsilon / \Lambda_{i}} \\
& +\left(1-\frac{\Lambda_{i} \exp ?\left(-\rho z_{\text {mix }} / \Lambda_{i}\right)}{\Lambda_{i}-\rho z_{\text {mix }}}\right) \frac{P_{i}(0)}{\lambda \rho z_{\text {mix }} / \Lambda_{i}+\rho \varepsilon / \Lambda_{i}} .
\end{aligned}
$$

In order to consider the effect of mixing, we assign concentration $C_{\mathrm{mix}}$ to the mixed material, i.e., to all material above $z_{\text {mix }}$, and a depth-dependent concentration (following Eq. A2) to material below depth $z_{\text {mix }}$.

\section{A2 Effect of mass wasting on calculated denudation rates}

\section{A2.1 Model setup}

As noted in the main text, erosion in mountain environments takes place both through incremental downslope transport of soils produced on hillslopes (often through diffusion-like processes) and through mass wasting events, such as landslides, slumps, and debris flows. Unlike diffusive erosion, mass wasting can remove material below the well-mixed soil zone and disturb the steady-state ${ }^{10} \mathrm{Be}$ concentrationdepth profiles. Such disturbance can affect the interpretation of denudation rate from ${ }^{10} \mathrm{Be}_{\mathrm{qtz}}$ in a given sediment sample (Brown et al., 1995; Niemi et al., 2005; Yanites et al., 2009).

We assess the potential bias from mass wasting on our estimates of long-term denudation rates for the Likhu by calculating the combinations of diffusive erosion ( $\left.\varepsilon_{\text {diff }}\right)$ and mass wasting denudation rate $\left(\varepsilon_{\mathrm{ls}}\right)$ that can explain the observed ${ }^{10} \mathrm{Be}_{\text {qtz }}$ data at each site. To do this, we model mass wasting based on repeated landslides of a characteristic size. In this case, for a given $\varepsilon_{\mathrm{ls}}$ and a characteristic depth of landslide $\left(z_{\mathrm{ls}}\right)$, the time interval between landslides is $\tau_{\mathrm{ls}}=z_{\mathrm{ls}} / \varepsilon_{\mathrm{ls}}$. Following a landslide event, the surface is reset to the ${ }^{10} \mathrm{Be}_{\mathrm{qtz}}$ concentration at depth $z_{\mathrm{ls}}$, and then ${ }^{10} \mathrm{Be}_{\mathrm{qtz}}$ accumulates as a function of time $t$, following Eq. (A1), until time $\tau_{\mathrm{ls}}$, when a landslide reoccurs. We calculate a ${ }^{10} \mathrm{Be}$ concentration depth profile $C^{\prime}(z)$ for $t=\tau_{1 \mathrm{~s}}$ from Eq. (A1) and truncate this profile at $z=z_{\text {ls }}$ to calculate the ${ }^{10} \mathrm{Be}$ inherited $\left(C_{\text {inh }}\right)$ immediately following a landslide event, i.e., the starting point for development of a new depth profile is defined by $C_{\mathrm{inh}}(0)=$ $C^{\prime}\left(z_{1 \mathrm{~s}}\right)$. For a given combination of $\varepsilon_{\mathrm{ls}}$ and $z_{\mathrm{ls}}$, the depth profile $C(z)^{*}$ expected immediately prior to landslide removal is then

$$
\begin{aligned}
& C(z)^{*}=C_{\mathrm{inh}}(z) \\
& +\sum_{i} \frac{P_{i}(0)}{\lambda+\rho \varepsilon / \Lambda_{i}} e^{-z \rho / \Lambda_{i}}\left(1-e^{-\tau\left(\lambda+\rho \varepsilon / \Lambda_{i}\right)}\right) .
\end{aligned}
$$

The ${ }^{10} \mathrm{Be}$ concentration of the mass wasting flux, $C_{\mathrm{ls}}$, is calculated by numerically integrating $C(z)^{*}$ above depth $z_{1 \mathrm{~s}}$ and determining the weighted average value. $C_{\text {sed }}$ is the weighted 

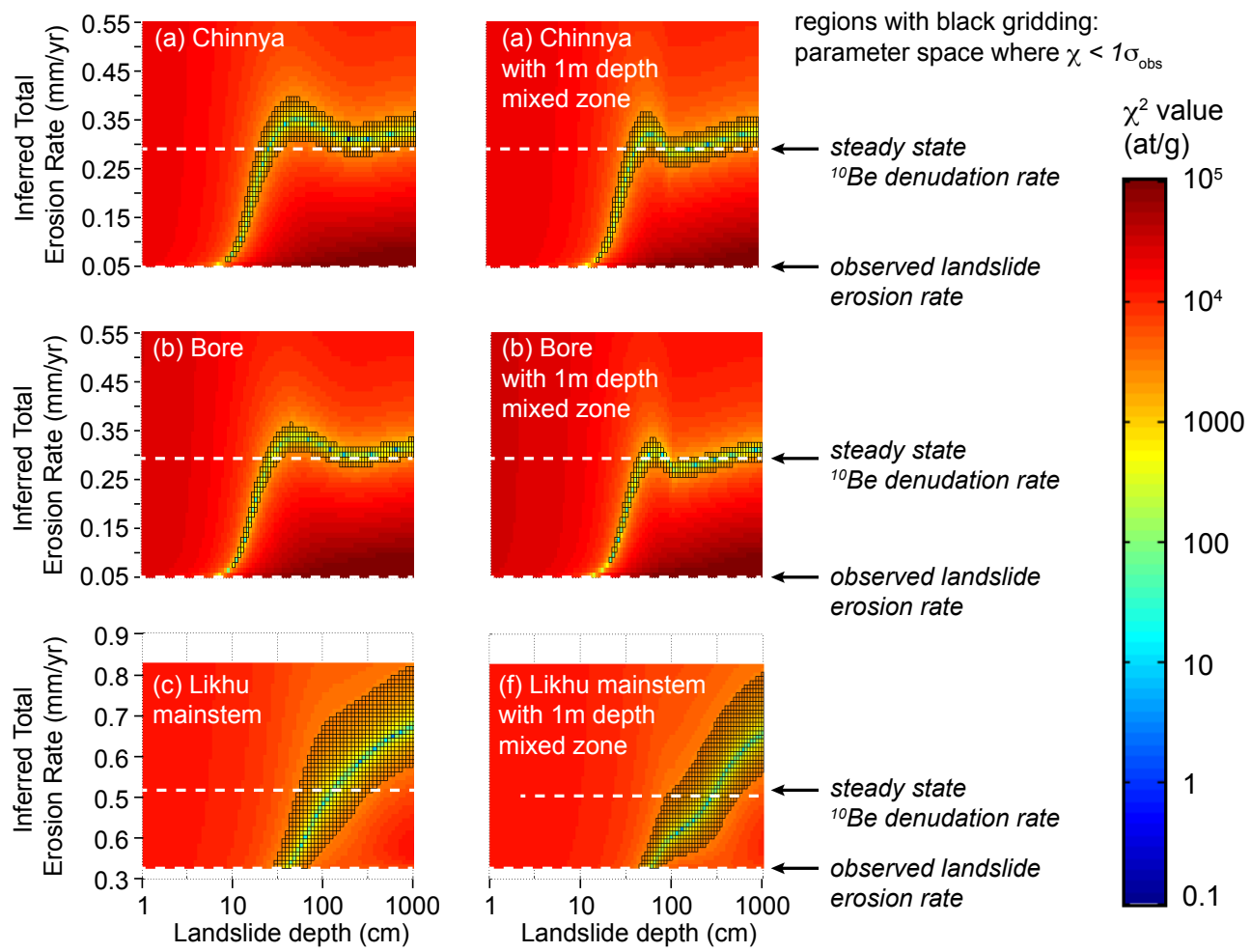

Figure A1. Results of model testing sensitivity of denudation rates estimates to mass wasting. Results from model calculating ${ }^{10} \mathrm{Be}_{\mathrm{qtz}}$ produced in sediment from repeated landslides of a characteristic depth, $z_{1 s}$, where the return time is fixed so that the total landslide flux adds up to the observed mass wasting flux in each catchment. Color shading shows the $\chi^{2}$ value describing the misfit between modeled ${ }^{10} \mathrm{Be}_{\mathrm{qtz}}$ concentration and the observed sediment ${ }^{10} \mathrm{Be}_{\mathrm{qtz}}$ concentration. Gridded regions define parameter space where the misfit $(\chi)$ is less than analytical uncertainty, reflecting combinations of $z_{1 \mathrm{~s}}$ and denudation rate that fit the data. The values of that fit the data (i.e., those within the gridded region) depend on the depth of landslides, but the pattern is relatively insensitive to the depth of mixing in the surface soil layer. The lowest possible value for is set by the imposed landslide erosion rate (the lower white, dashed line). For very small landslides (which must occur more frequently), the river sediment ${ }^{10} \mathrm{Be}$ concentration could be explained by total denudation rates that approach this landslide rate, requiring little to no additional, non-landslide erosion. In this case, a long-term denudation rate calculated assuming steady state would overestimate actual long-term rates (i.e., for values of $z_{1 \mathrm{~s}}$ on the $x$ axis where white dashed line for steady-state rate is higher than the $\chi^{2}$ valley). However, small landslides $(<50 \mathrm{~cm})$ probably do not dominate the erosional budget, and for realistic depth of landslides in the Bore and Chinnya $(>\sim 50 \mathrm{~cm})$, rates calculated on the basis of a steady-state assumption closely approximate the long-term rate in the model (where the $\chi^{2}$ valley coincides with the steady-state value in panels (a), (b), (d), and (e)). For the Likhu main stem (c, f), with higher landslide erosion rate, potential bias is more significant, though the larger size of this catchment may average stochastic landslide events (cf. Niemi et al., 2005; Yanites et al., 2007). Note that the model shown here is for a highly simplified system with landslides of uniform size and return frequency, and fixed landslide erosion rate.

average of $C_{\mathrm{ls}}$ plus the contribution from diffusive erosion, which removes material from the top of soil profiles:

$C_{\text {sed }}=\left(\varepsilon_{1 \mathrm{~s}} C_{\mathrm{ls}}+\varepsilon_{\mathrm{diff}} C_{\mathrm{soil}}\right) /\left(\varepsilon_{\mathrm{ls}}+\varepsilon_{\mathrm{diff}}\right)$,

where $C_{\text {soil }}$ is the composition of material eroded from the surface. For the purposes of this modeling exercise, we assume that landslides of the same size occur periodically across the landscape to maintain spatially uniform rates of lowering over long timescales, so for any given point on the landscape there is a uniform chance of having an effective age varying between $t=0$ and $t=\tau_{1 \mathrm{~s}}$. We determine $C(z=0, t)$ from Eq. (A5) for 1-year intervals, integrate the resulting distribution numerically between $t=0$ and $\tau_{\mathrm{ls}}$, and assign $C_{\text {soil }}$ as the weighted average concentration.
In addition to considering profiles defined by Eq. (A5) alone, we also explore the additional case where the surface layer that forms following each landslide event is continuously mixed to a depth of $z_{\text {mix }}$. We choose $z_{\text {mix }}=1 \mathrm{~m}$ as broadly representative of soil depth in the Nepal Middle Hills in order to illustrate the effect of mixing. In this case, the depth profile prior to landslide occurrence is defined by Eq. (A3) for $z<1 \mathrm{~m}$ (with the addition of a term for inherited ${ }^{10} \mathrm{Be}$ ) and by Eq. (A5) for $z>1 \mathrm{~m} . C_{\mathrm{ls}}$ is calculated from the integration of the profile to depth $z_{1 \mathrm{~s}}$, as in the case without mixing. Similarly, $C_{\text {soil }}$ is calculated as in the case above without mixing by instead determining the weighted average concentration for the surface of all profiles with effective 
Expected result from anthropogenic disturbance,

assuming background denudation is steady-state process (equivalent to landslides all shallower than mixing depth)
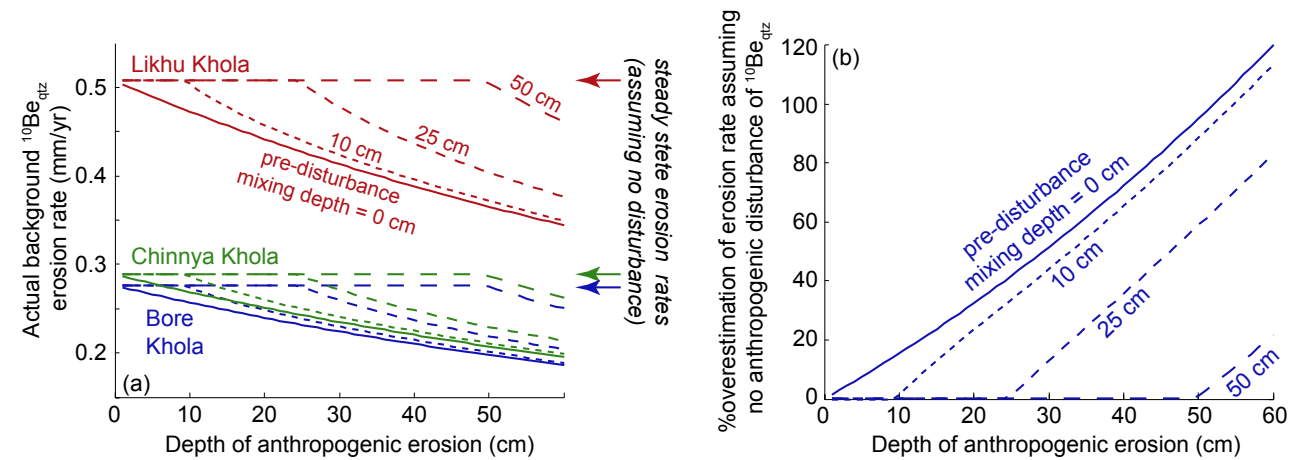

Expected result from anthropogenic disturbance,

assuming background denudation is purely mass-wasting process of single depth (landslides all deeper than mixing depth)
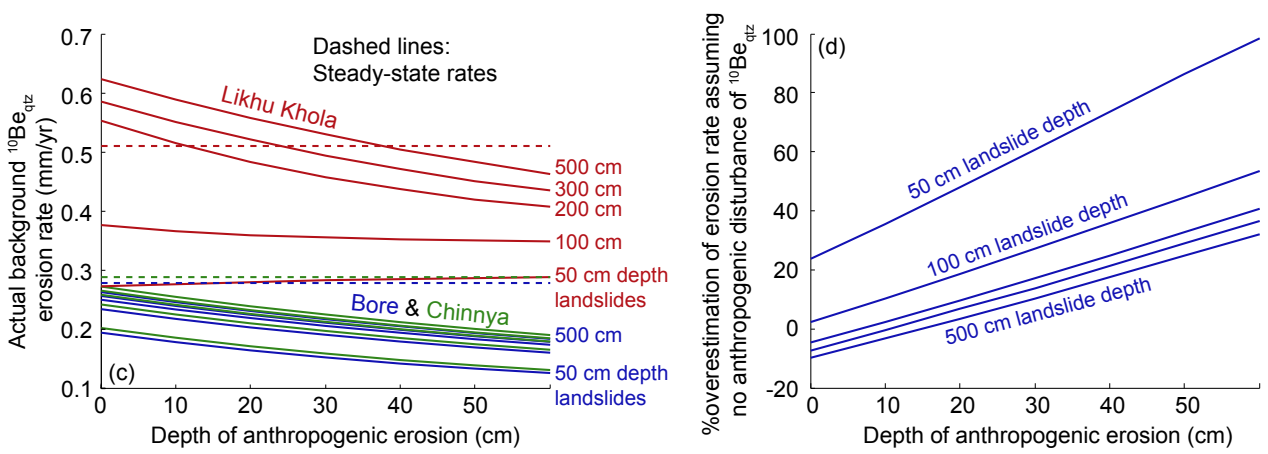

Figure A2. Results of model testing sensitivity of denudation rates estimates to agricultural reworking. Effect of anthropogenic disturbance on long-term erosion rates inferred from ${ }^{10} \mathrm{Be}_{\mathrm{qtz}}$, as a result of increased erosion removing soil from below the surface. Panels (a) and (b) show the case for steady-state denudation prior to disturbance, and (c) and (d) show the case for mass wasting denudation. In (a) and (b), the effect of disturbance depends on the depth of the mixed layer relative to the depth of agricultural reworking. In (c) and (d), mixing is not considered explicitly, for simplicity. The implied erosion rate at $z_{\mathrm{e}}=0$ in (c) and (d) differs from the steady-state erosion rate, because of the influence of mass wasting depth and recurrence interval on inferred rates (cf. Fig. A1). When the depth of perturbation is lower than the depth of natural mixing, steady-state denudation rates (from Eq. 1) yield representative long-term rates (e.g., horizontal portions of the lines in $\mathbf{a}, \mathbf{b})$. When the depth of perturbation exceeds the depth of mixing, the enhanced supply of shielded material with low ${ }^{10} \mathrm{Be}$ concentrations biases the river sediment and means that rates calculated assuming steady state would overestimate the actual long-term denudation rate in the absence of anthropogenic activity (by a proportion shown in panel b).

age between $t=0$ and $t=\tau_{\mathrm{ls}} . C_{\mathrm{ls}}$ and $C_{\text {soil }}$ are then used in Eq. (6), as above.

It is important to emphasize that this model is not intended to provide a complete simulation of landslide occurrence but is used to explore the potential scale of bias in inferred denudation rates that may be expected as a result of mass wasting processes.

\section{A2.2 Applying the mass wasting model to the Likhu case}

To apply our simple landslide recurrence model to the Likhu data, we fix the total mass wasting denudation rate $\left(\varepsilon_{\mathrm{ls}}\right)$ for a given site to match the measured mass wasting flux in each catchment, equivalent to $0.325 \mathrm{~mm} \mathrm{yr}^{-1}$ denudation for the Likhu and $0.05 \mathrm{~mm} \mathrm{yr}^{-1}$ for the Bore and Chinnya (Table 4). We consider a range of values for $z_{\mathrm{ls}}$ and $\varepsilon$ and determine the misfit between $C_{\text {sed }}$ (from Eq. A6) and $C_{\text {meas }}$, the measured ${ }^{10} \mathrm{Be}_{\mathrm{qtz}}$ concentration from each catchment, as $\chi^{2}=\left(C_{\text {sed }}-C_{\text {meas }}\right)^{2}$. Model results are shown in Fig. A1. A subset of the sampled parameter space is statistically consistent with the measured ${ }^{10} \mathrm{Be}_{\mathrm{qtz}}$, specifically those combinations of $z_{\text {ls }}$ and $\varepsilon$ that yield $\chi<\sigma_{C}$, where $\sigma_{C}$ is the uncertainty on the concentration measurements. The erosion rates associated with these misfits define a valley that illustrates how possible solutions for long-term erosion rate depend on the nature of mass wasting, and specifically on the depth of repeated failures. In the real world, landslides are not all of the same size, as assumed in our model, but instead generally follow an inverse gamma distribution (e.g., Malamud et al., 2004). Considering the full size distribution requires a more complete stochastic model (cf. Niemi et al., 2005; Yanites et al., 2009), but Fig. A1 offers a first-order view of the degree to which mass wasting may affect calculated rates and 
provides a framework for assessing bias in our inferred denudation rates in the Likhu Basin.

\section{A2.3 Mass wasting model results, and implications for inferred rates}

It can readily be seen from the regions defining the lowest $\chi^{2}$ values in Fig. A1 that the long-term total denudation rate inferred for a given ${ }^{10} \mathrm{Be}_{\mathrm{qtz}}$ concentration in the Likhu catchments depends on the depth and associated return time of landslides. For a given catchment, more shallow landslides must reoccur more frequently, resulting in more frequent resetting of the ${ }^{10} \mathrm{Be}$ profile and therefore requiring lower rates of soil production to produce the observed ${ }^{10} \mathrm{Be}$ concentration in sediment. Thus shallower characteristic landslides mean lower total best-fit denudations rates in the model. In contrast, deeper, less frequent landslides allow more ${ }^{10} \mathrm{Be}$ accumulation, requiring more soil production and thus higher total denudation rates to produce the observed ${ }^{10} \mathrm{Be}$ concentration. Inferred rates in Fig. A1 cannot be lower than the observed landslide erosion rates, since these set the minimum values for total denudation in the model. Where the $\chi^{2}$ valleys in Fig. A1 intersect the white dashed line defining the observed landslide rate, landslides are small and frequent enough that landslide erosion could effectively explain the ${ }^{10} \mathrm{Be}$ concentration on their own, approaching zero nonlandslide erosion (so the total inferred erosion rate equals the imposed landslide rate).

For relatively large characteristic landslide depths, the best-fit (lowest $\chi^{2}$ ) region converges on a value close to (in some cases slightly higher than) the denudation rate calculated assuming steady state (e.g., for depths $>\sim 50 \mathrm{~cm}$ in Fig. A1a, b, d, e). This observation suggests that the steadystate rate is likely to provide a relatively accurate approximation under these conditions. When landslide rates are higher (e.g., the Likhu main stem in Fig. A1c, f), deep landslides would mean that the best-fit result would require a higher denudation rate than calculated assuming steady state (i.e., the lowest $\chi^{2}$ region lies above the white dotted line that defines the rate calculated for steady state). If characteristic landslides are shallower (and by definition in the model more frequent), then the best statistical fit yields lower denudation rates than would be calculated assuming steady state (i.e., in Fig. A1 at lower landslide depths, the lowest $\chi^{2}$ region dips below the white dotted line that defines the rate calculated for steady state). Thus, if mass wasting consists only of small, frequent failures, then the actual long-term denudation rate may be lower than implied by the steady-state calculation.

The associated bias is small for the Bore and the Chinnya, and is within the uncertainty in the inferred steady-state denudation rate, unless landslides are all very small (i.e., in the case that all landslides were $<\sim 50 \mathrm{~cm}$ depth). The flux from such extremely shallow landslide probably does not dominate the erosional budget (Gerrard and Gardner, 2002), so the effect of these landslides is not likely to have an impor- tant effect on our estimates of denudation rate. We thus view the steady-state long-term denudation rates (reported in Table 3) as reasonable estimates for the Bore and the Chinnya.

For the Likhu main stem, the potential bias could be more significant, since there is a range of total erosion rates that can describe the data for plausible landslide depths (e.g., $0.5-10 \mathrm{~m}$ depths; Gerrard and Gardner, 2002). The catchment area of the Likhu Khola is large enough $\left(>100 \mathrm{~km}^{2}\right)$ that stochastic landslide processes, i.e., the occurrence of a range of different-sized landslides across the catchment area at any given time, may be expected to average across the catchment area, yielding an integrated ${ }^{10} \mathrm{Be}_{\mathrm{qtz}}$-derived denudation rate that approximates the steady-state value (cf. results from stochastic models from Niemi et al., 2005; Yanites et al., 2009). As a result, the inferred steady-state denudation rate from the Likhu main stem may be representative of the long-term rate, although we emphasize caution in the interpretation of this value. In any case, we do not use the rates from the Likhu main stem in our comparison to short-term erosion rates, and we provide the result from this site primarily for reference.

Event-triggered landslide pulses can mean that measured ${ }^{10} \mathrm{Be}_{\mathrm{qtz}}$ may not accurately reflect long-term concentrations; samples collected soon after a large-magnitude, lowfrequency event may overestimate rates, while those collected long after such an event may underestimate actual rates (Ouimet, 2009; West et al., 2014). Since there were no known large-magnitude events within several decades (at least 10-20 years) of when our samples were collected, we anticipate that our observed concentrations represent an upper limit of long-term ${ }^{10} \mathrm{Be}_{\mathrm{qtz}}$, and thus provide a lower limit on estimated denudation rate. This suggests that any bias from the time of sampling would not change our overall conclusions (e.g., in Fig. 4 of the main text), i.e., that short-term, anthropogenically perturbed rates do not appear to be significantly higher than long-term denudation rates in the Likhu Khola.

\section{A3 Anthropogenic perturbation of ${ }^{10} \mathrm{Be}_{\mathrm{qtz}}$ in eroding sediment?}

\section{A3.1 Agricultural reworking of simple steady-state profile}

The supply of cosmogenically shielded rock to stream sediment as a result of agricultural or other land use activity can, like mass wasting, disturb the sourcing of sediment from depth $z=0$ and so can potentially bias calculation of longterm denudation rates. If land use activities generate river sediment that is characterized by lower ${ }^{10} \mathrm{Be}_{\text {qtz }}$ than background denudation, then the estimated denudation rates may be higher than the actual long-term background rate. For example, Brown et al. (1998) observed $\sim 2$-fold higher cosmogenically derived rates in an agriculturally disturbed catchment in Puerto Rico when compared to an undisturbed catch- 
ment, and von Blanckenburg et al. (2004) suggested that the dissection of rills in agricultural areas could explain the discrepancy between inferred denudation rates in large river basins versus small headwater catchments in the Sri Lanka highlands. We have assessed the effect of anthropogenic perturbation on estimates of ${ }^{10} \mathrm{Be}_{\mathrm{qtz}}$-derived denudation rates in the Likhu Khola by considering theoretical ${ }^{10} \mathrm{Be}_{\mathrm{qtz}}$ vs. depth curves (from Eq. A2) and determining an integrated average ${ }^{10} \mathrm{Be}$ concentration, $\hat{\mathrm{C}}$, for material that is eroding from each depth profile. We find $\hat{\mathrm{C}}$ by numerically integrating the profile over depth $z_{\mathrm{e}}$, the depth of erosion. For unperturbed steady-state denudation, the depth of eroding material is zero, because erosion occurs from the top of the profile (Granger and Riebe, 2007). Land use perturbation may contribute material from greater depth, for example through tilling and/or enhanced soil erosion. We calculate integrated $C_{\text {pred }}$ for a given depth $z_{\mathrm{e}}$ of anthropogenic erosion and find the steady-state depth profile from Eq. (A2) that minimizes the chi-square misfit statistic $\chi^{2}=\left(C_{\text {pred }}-C_{\text {meas }}\right)^{2}$, where $C_{\text {meas }}$ is the measured concentration in each sediment sample. The denudation rate $\varepsilon$ associated with the best-fit profile represents the inferred "real background" (i.e., unperturbed) steady-state rate. Since the depth of anthropogenic erosion is not precisely known, we plot variability in $\varepsilon$ as a function of $z_{\mathrm{e}}$ (Fig. S2). For $z_{\mathrm{e}}=0$, the resulting value for $\varepsilon$ matches the rate calculated directly from solving Eq. (1) (main text), as expected. For $z_{\mathrm{e}}>0$, the resulting value of $\varepsilon$ is typically somewhat lower than the steady-state value.

\section{A3.2 Agricultural reworking of profile with mixed soil layer}

Mixing will affect the calculation of $\hat{\mathrm{C}}$ for a given perturbed erosion depth. We consider a range of possible mixing depths $z_{\text {mix }}$, and in each case assign concentration $C_{\text {mix }}$ to the mixed material (Eq. A4) and a depth-dependent concentration (following Eq. A2) to material below depth $z_{\text {mix }}$. We then repeat the $\chi^{2}$ inversion for the range of depths of anthropogenic perturbation (Fig. A2).

\section{A3.3 Agricultural reworking of profile characterized by mass wasting}

The effect of agricultural reworking of the surface may differ if the depth profile of ${ }^{10} \mathrm{Be}_{\mathrm{qtz}}$ is defined by repeated mass wasting, rather than by steady-state erosion (as assumed in the calculations above). Many different pre-perturbation depth profiles are theoretically plausible and consistent with the measured ${ }^{10} \mathrm{Be}_{\mathrm{qtz}}$, depending on the combinations of landslide depth, return time, and soil production (Fig. A1). This complicates quantifying the effect of agricultural reworking; accurately predicting the effect of agricultural disturbance would require knowing the distribution of landslide depths and ages across the landscape, and the spatial relation of landslides to the extent of agricultural reworking.
We can still explore the effect of agricultural reworking of a mass-wasting-dominated landscape on calculated denudation rates by making some simplifying assumptions. We consider a few example cases based on the mass wasting model presented in Sect. A2. We modify Eq. (A6) to account for anthropogenic disturbance by assuming that agriculture removes the layer of each profile down to depth $z_{\mathrm{e}}$, and we calculate $C_{\text {soil }}$ to include the additional input. We then recalculate the best-fit total erosion rate for a given landslide depth and recurrence time. As in the case above for steadystate erosion, we repeat the exercise for a range of depths of anthropogenic perturbation in order to yield a plot of $\varepsilon$ vs. $z_{e}$ for a given depth of characteristic landslides (Fig. A2c). We consider a range of landslide depths and associated recurrence timescales. This is a simplified framework for illustrating the effects of mass wasting; actual landslide failures are expected to span a range of depths, but the simple model allows us to test how much bias may be introduced under some plausible scenarios.

\section{A4 Results of model of anthropogenic perturbation of ${ }^{10} \mathrm{Be}$}

As expected, when the depth of perturbation is lower than the depth of natural mixing $\left(z_{e}<z_{\text {mix }}\right)$, steady-state denudation rates (from Eq. 1) yield representative long-term rates. For example, if the pre-anthropogenic mixing depth was $25 \mathrm{~cm}$, and the depth of anthropogenic erosion was $20 \mathrm{~cm}$, the actual erosion rate would be the same as that calculated assuming steady state (i.e., the horizontal portions of the lines in Fig. A2a, equivalent to $0 \%$ values in Fig. A2b). This result is consistent with the conclusions of Granger and Riebe (2007) and is explained by the fact that any material delivered to stream sediment by anthropogenic reworking comes from the homogeneous mixed layer at the surface. Since this material is homogeneous with respect to ${ }^{10} \mathrm{Be}$ concentration, more input to stream sediment as a result of anthropogenic activity does not affect the measured ${ }^{10} \mathrm{Be}$ concentration and consequently the calculated denudation rate.

On the other hand, if land-use perturbation exceeds the depth of natural mixing $\left(z_{e}>z_{\text {mix }}\right)$, then rates calculated from Eq. (1) can overestimate actual rates in the Likhu Khola by as much as a factor of $\sim 2$. For example, if the predisturbance mixing depth $\left(z_{\operatorname{mix}}\right)$ was $10 \mathrm{~cm}$ and the depth of anthropogenic erosion $\left(z_{e}\right)$ was $20 \mathrm{~cm}$, then the denudation rates calculated assuming steady state may overestimate actual rates by $\sim 25 \%$. This overestimation results because the stream sediment being measured includes material with low ${ }^{10} \mathrm{Be}$ concentration introduced by anthropogenic reworking; this low concentration material will bias calculated rates to higher values than is representative of actual long-term rates.

These relatively simple relations are somewhat more complicated when considering the anthropogenic disturbance of a landslide-dominated system. In this case, the magnitude of bias depends on the landslide characteristics (see Fig. A1, 
and discussion above). Moreover, the model considered here does not account for the effect of land use in enhancing rill and gully erosion, which may result in highly shielded material from greater depth being supplied to stream sediment (cf. von Blanckenburg et al., 2004).

In the case of the Likhu, soil depths are on the order of $100-200 \mathrm{~cm}$, and the steep slopes mean that downslope transport is expected to mix soils (cf. Heimsath et al., 1997), so any bias in long-term rates from anthropogenic perturbation is likely to be small. Moreover, the sites we use to establish reference long-term rates (the headwater Bore and Chinnya catchments) have minimal agricultural influence. This latter observation in particular gives us increased confidence in making the key comparisons in the main text, where we focus our analysis on the magnitude of land use effects on erosion rates in the Middle Hills. 


\section{The Supplement related to this article is available online at doi:10.5194/esurf-3-363-2015-supplement.}

Acknowledgements. Catherine Pomies and Hazel Chapman are acknowledged for help with sample collection in the field. This manuscript benefited from discussions with Friedhelm von Blanckenburg and Roman DiBiase, and from thorough analysis with many constructive comments from two reviewers and the associate editor (S. Mudd). A. J. West received financial support for this work through UK Natural Environment Research Council (NERC) research fellowship NE/C517376/1 and US National Science Foundation (NSF) grant EAR-1053504. The ASTER French AMS national facility (CEREGE, Aix-en-Provence) is supported by the INSU/CNRS, and the ANR through the "Projets thématiques d'excellence" program for the "Equipements d'excellence" ASTER-CEREGE action, IRD, and CEA. M. Arnold, G. Aumaître, and $\mathrm{K}$. Keddadouche are thanked for their valuable assistance during ${ }^{10} \mathrm{Be}$ measurements.

Edited by: S. Mudd

\section{References}

Aguilar, G., Carretier, S., Regard, V., Vassallo, R., Riquelme, R., and Martinod, J.: Grain size-dependent ${ }^{10} \mathrm{Be}$ concentrations in alluvial stream sediment of the Huasco Valley, a semi-arid Andes region, Quatern. Geochronol., 19, 163-172, doi:10.1016/j.quageo.2013.01.011, 2014.

Andermann, C., Crave, A., Gloaguen, R., Davy, P., and Bonnet, S.: Connecting source and transport: suspended sediments in the Nepal Himalayas, Earth Planet. Sc. Lett., 351-352, 158-170, doi:10.1016/j.eps1.2012.06.059, 2012.

Asia Development Bank and ICIMOD: Environmental Assessment of Nepal: Emerging Issues and Challenges, Kathmandu, 2006.

Bai, Z. G., Dent, D. L., Olsson, L., and Schaepman, M. E.: Proxy global assessment of land degradation, Soil Use Manage., 24, 223-234, doi:10.1111/j.1475-2743.2008.00169.x, 2008.

Bajracharya, R. M., Sharma, S., and Clemente, R.: Discharge and sediment loads of two streams in the mid-hills of central Nepal, Himal. J. Sci., 2, 2004.

Balco, G., Stone, J. O., Lifton, N. A., and Dunai, T. J.: A complete and easily accessible means of calculating surface exposure ages or erosion rates from ${ }^{10} \mathrm{Be}$ and ${ }^{26} \mathrm{Al}$ measurements, Quatern. Geochronol., 3, 174-195, doi:10.1016/j.quageo.2007.12.001, 2008.

Belmont, P., Pazzaglia, F. J., and Gosse, J. C.: Cosmogenic ${ }^{10} \mathrm{Be}$ as a tracer for hillslope and channel sediment dynamics in the Clearwater River, western Washington State, Earth Planet. Sc. Lett., 264, 123-135, doi:10.1016/j.epsl.2007.09.013, 2007.

Bierman, P. R. and Nichols, K. K.: Rock to Sediment - Slope to sea with ${ }^{10} \mathrm{Be}$ - rates of landscape change, Annu. Rev. Earth Planet. Sci., 32, 215-255, doi:10.1146/annurev.earth.32.101802.120539, 2004.

Blaikie, P. M. and Sadeque, S. Z.: Policy in High Places: Environment and Development in the Himalayas, ICIMOD, Nepal, 2000.
Boardman, J.: Soil erosion science: Reflections on the limitations of current approaches, CATENA, 68, 73-86, doi:10.1016/j.catena.2006.03.007, 2006.

Boix-Fayos, C., Martínez-Mena, M., Arnau-Rosalén, E., CalvoCases, A., Castillo, V., and Albaladejo, J.: Measuring soil erosion by field plots: Understanding the sources of variation, Earth-Sci Rev., 78, 267-285, doi:10.1016/j.earscirev.2006.05.005, 2006.

Brasington, J. and Richards, K.: Turbidity and suspended sediment dynamics in small catchments in the Nepal Middle Hills, Hydrol. Process., 14, 2559-2574, doi:10.1002/10991085(20001015)14:14<2559::AID-HYP114>3.0.CO;2-E, 2000.

Braucher, R., Merchel, S., Borgomano, J., and Bourlès, D. L.: Production of cosmogenic radionuclides at great depth: a multi element approach, Earth Planet. Sc. Lett., 309, 1-9, doi:10.1016/j.eps1.2011.06.036, 2011.

Braucher, R., Bourlès, D., Merchel, S., Vidal Romani, J., FernadezMosquera, D., Marti, K., Léanni, L., Chauvet, F., Arnold, M., Aumaître, G., and Keddadouche, K.: Determination of muon attenuation lengths in depth profiles from in situ produced cosmogenic nuclides, Nucl. Instrum. Meth. Phys. Res. Sect. B, 294, 484-490, doi:10.1016/j.nimb.2012.05.023, 2013.

Brown, E. T., Stallard, R. F., Larsen, M. C., and Raisbeck, G. M.: Denudation rates determined from the accumulation of in situ-produced ${ }^{10} \mathrm{Be}$ in the Luquillo Experimental Forest, Puerto Rico, Earth Planet. Sc. Lett., 129, 193-202, doi:10.1016/0012821X(94)00249-X, 1995.

Brown, E. T., Stallard, R. F., Larsen, M. C., Bourlès, D. L., Raisbeck, G. M., and Yiou, F.: Determination of predevelopment denudation rates of an agricultural watershed (Cayaguás River, Puerto Rico) using in-situ-produced ${ }^{10} \mathrm{Be}$ in river-borne quartz, Earth Planet. Sc. Lett., 160, 723-728, doi:10.1016/S0012821X(98)00123-X, 1998.

Brown, L.: World population growth, soil erosion, and food security, Science, 214, 995-1002, doi:10.1126/science.7302578, 1981.

Bruijnzeel, L. A. and Critchley, W. R. S.: A new approach towards the quantification of runoff and eroded sediment from bench terraces in humid tropical steeplands and its application in south-central Java, Indonesia, in Advances in Hillslope Processes, edited by: Anderson, M. G. and Brooks, S. M., Wiley, New York, 1996.

Burton, S., Shah, P. B., and Schreier, H.: Soil degradation from converting forest land into agriculture in the Chitwan district of Nepal, Mountain Res. Develop., 9, 393-404, doi:10.2307/3673587, 1989.

Chalise, S. R. and Khanal, N. R.: Erosion processes and their implications in sustainable management of watersheds in Nepal Himalayas, FRIEND'97 - Regional hydrology: Concepts and models for sustainable water resource management, Proceedings of the Postojna, Solvenia, Conference, September-October 1997, IAHS Publ no. 246, 1997.

Chow, T. L., Rees, H. W., and Daigle, J. L.: Effectiveness of terraces/grassed waterway systems for soil and water conservation: a field evaluation, J. Soil Water Conserv., 54, 577-583, 1999.

Clapp, E. M., Bierman, P. R., and Caffee, M.: Using ${ }^{10} \mathrm{Be}$ and ${ }^{26} \mathrm{Al}$ to determine sediment generation rates and identify sediment source areas in an arid region drainage basin, Geomorphology, 45, 89-104, doi:10.1016/S0169-555X(01)00191-X, 2002. 
Costa, J. E.: Effects of agriculture on erosion and sedimentation in the Piedmont Province, Maryland, Geol. Soc. Am. Bull., 86, 1281-1286, doi:10.1130/00167606(1975)86<1281:EOAOEA>2.0.CO;2, 1975.

Covault, J. A., Craddock, W. H., Romans, B. W., Fildani, A., and Gosai, M.: Spatial and temporal variations in landscape evolution: historic and longer-term sediment flux through global catchments, J. Geol., 121, 35-56, doi:10.1086/668680, 2013.

De Vente, J., Poesen, J., Arabkhedri, M., and Verstraeten, G.: The sediment delivery problem revisited, Prog. Phys. Geogr., 31, 155-178, doi:10.1177/0309133307076485, 2007.

Dunai, T.: Cosmogenic Nuclides: Principles, Concepts and Applications in the Earth Surface Sciences, Cambridge University Press, Cambridge, 2010.

Eckholm, E. P.: The Deterioration of Mountain Environments: ecological stress in the highlands of Asia, Latin America, and Africa takes a mounting social toll, Science, 189, 764-770, doi:10.1126/science.189.4205.764, 1975.

Ferrier, K. L., Kirchner, J. W., and Finkel, R. C.: Erosion rates over millennial and decadal timescales at Caspar Creek and Redwood Creek, Northern California Coast Ranges, Earth Surf. Process. Landforms, 30, 1025-1038, doi:10.1002/esp.1260, 2005.

Froehlich, W. and Starkel, L.: The effects of deforestation on slope and channel evolution in the tectonically active Darjeeling Himalaya, Earth Surf. Process. Landforms, 18, 285-290, doi:10.1002/esp.3290180309, 1993.

Gabet, E., Burbank, D., Pratt-Sitaula, B., Putkonen, J., and Bookhagen, B.: Modern erosion rates in the High Himalayas of Nepal, Earth Planet. Sc. Lett., 267, 482-494, doi:10.1016/j.epsl.2007.11.059, 2008.

Gallo, F. and Lavé, J.: Evolution of a large landslide in the High Himalaya of central Nepal during the last half-century, Geomorphology, 223, 20-32, doi:10.1016/j.geomorph.2014.06.021, 2014.

Gardner, R. A. M. and Jenkins, A.: Land use, soil conservation, and water resource management in the Nepal Middle Hills, Overseas Development Administration, London, 1995.

Gardner, R. A. M. and Gerrard, A. J.: Relationships between runoff and land degradation on non-cultivated land in the Middle Hills of Nepal, Int. J. Sustain. Develop. World Ecol., 9, 59-73, doi:10.1080/13504500209470103, 2002.

Gardner, R. A. M. and Gerrard, A. J.: Runoff and soil erosion on cultivated rainfed terraces in the Middle Hills of Nepal, Appl. Geogr., 23, 23-45, doi:10.1016/S0143-6228(02)00069-3, 2003.

Gardner, R. A. M. and Gerrard, A. J.: Soil loss on noncultivated land in the Middle Hills of Nepal, Phys. Geogr., 22, 376-393, doi:10.1080/02723646.2001.10642750, 2001.

Gerrard, A. J. and Gardner, R. A. M.: The nature and management implications of landsliding on irrigated terraces in the Middle Hills of Nepal, Int. J. Sust. Dev. World, 7, 229-235, doi:10.1080/13504500009470043, 2000.

Gerrard, A. J. and Gardner, R. A. M.: Landsliding in the Likhu Khola drainage basin, Middle Hills of Nepal, Phys. Geogr., 20, 240-255, doi:10.1080/02723646.1999.10642678, 1999.

Gerrard, A. J. and Gardner, R. A. M.: Relationships Between Landsliding and Land Use in the Likhu Khola Drainage Basin, Middle Hills, Nepal, Mountain Res. Develop., 22, 48-55, doi:10.1659/0276-4741(2002)022[0048:RBLALU]2.0.CO;2, 2002.
Godard, V., Bourlès, D. L., Spinabella, F., Burbank, D. W., Bookhagen, B., Fisher, G. B., Moulin, A. and Léanni, L.: Dominance of tectonics over climate in Himalayan denudation, Geology, 42, 243-246, doi:10.1130/G35342.1, 2014.

Godard, V., Burbank, D. W., Bourlès, D. L., Bookhagen, B., Braucher, R. and Fisher, G. B.: Impact of glacial erosion on ${ }^{10} \mathrm{Be}$ concentrations in fluvial sediments of the Marsyandi catchment, central Nepal, J. Geophys. Res., 117, F03013, doi:10.1029/2011JF002230, 2012.

Goethals, M. M., Hetzel, R., Niedermann, S., Wittmann, H., Fenton, C. R., Kubik, P. W., Christl, M., and von Blanckenburg, F.: An improved experimental determination of cosmogenic ${ }^{10} \mathrm{Be} /{ }^{21} \mathrm{Ne}$ and ${ }^{26} \mathrm{Al} /{ }^{21} \mathrm{Ne}$ production ratios in quartz, Earth Planet. Sc. Lett., 284, 187-198, doi:10.1016/j.eps1.2009.04.027, 2009.

Granger, D. E., Lifton, N. A. and Willenbring, J. K.: A cosmic trip: 25 years of cosmogenic nuclides in geology, Geological Society of America Bulletin, 125, 1379-1402, doi:10.1130/B30774.1, 2013.

Granger, D. E. and Riebe, C. S.: 5.19 - Cosmogenic Nuclides in Weathering and Erosion, in Treatise on Geochemistry, edited by: Holland, H. D. and Turekian, K. K., 1-43, Pergamon, Oxford, 2007.

Granger, D. E., Kirchner, J., and Finkel, R.: Spatially averaged long-term erosion rates measured from in situ-produced cosmogenic nuclides in alluvial sediment, J. Geol., 104, 249-257, doi:10.1086/629823, 1996.

Hamilton, L. S.: What Are the Impacts of Himalayan Deforestation on the Ganges-Brahmaputra Lowlands and Delta? Assumptions and Facts, Proceedings of the Mohonk Mountain Conference: The Himalaya-Ganges Problem (Aug., 1987), 256-263, 1987.

Harden, C. P.: Land use, soil erosion, and reservoir sedimentation in an Andean drainage basin in Ecuador, Mt. Res. Dev., 13, 177184, doi:10.2307/3673635, 1993.

Heimsath, A. M.: A Comparison of Streamflow from Agricultural and Forested Watersheds in the Middle Hills, Nepal, Yale University School of Forestry and Environmental Studies, New Haven, 1993.

Heimsath, A. M., DiBiase, R. A., and Whipple, K. X.: Soil production limits and the transition to bedrock-dominated landscapes, Nat. Geosci., 5, 210-214, doi:10.1038/ngeo1380, 2012.

Heimsath, A. M., Dietrich, W. E., Nishiizumi, K., and Finkel, R. C.: The soil production function and landscape equilibrium, Nature, 388, 358-361, doi:10.1038/41056, 1997.

Hewawasam, T., von Blanckenburg, F., Schaller, M., and Kubik, P.: Increase of human over natural erosion rates in tropical highlands constrained by cosmogenic nuclides, Geology, 31, 597-600, doi:10.1130/0091-7613(2003)031<0597:IOHONE>2.0.CO;2, 2003.

Hovius, N., Stark, C., and Allen, P.: Sediment flux from a mountain belt derived by landslide mapping, Geology, 25, 231-234, doi:10.1130/0091-7613(1997)025<0231:SFFAMB>2.3.CO;2, 1997.

Hudson, N. W.: Field measurement of soil erosion and runoff, Food and Agriculture Organization of the United Nations, Rome, 1993.

Inbar, M. and Llerena, C. A.: Erosion Processes in High Mountain Agricultural Terraces in Peru, Mountain Re- 
search and Development, 20, 72-79, doi:10.1659/02764741(2000)020[0072:EPIHMA]2.0.CO;2, 2000.

Ives, J. and Messerli, B.: The Himalayan Dilemma: Reconciling development and conservation, Routledge, New York, 1989.

Jha, M. K. and Paudel, R. C.: Erosion Predictions by Empirical Models in a Mountainous Watershed in Nepal, J. Spat. Hydrol., 10, 89-102, 2010.

Keefer, D.: The importance of earthquake-induced landslides to long-term slope erosion and slope-failure hazards in seismically active regions, Geomorphology, 10, 265-284, doi:10.1016/0169555X(94)90021-3, 1994.

Kirchner, J., Finkel, R., Riebe, C., Granger, D., Clayton, J., King, J., and Megahan, W.: Mountain erosion over $10 \mathrm{yr}, 10 \mathrm{k} . \mathrm{y}$. , and 10 m.y. time scales, Geology, 29, 591-594, doi:10.1130/00917613(2001)029<0591:MEOYKY>2.0.CO;2, 2001.

Kober, F., Hippe, K., Salcher, B., Ivy-Ochs, S., Kubik, P. W., Wacker, L., and Hählen, N.: Debris-flow-dependent variation of cosmogenically derived catchment-wide denudation rates, Geology, 40, 935-938, doi:10.1130/G33406.1, 2012.

Kohl, C. and Nishiizumi, K.: Chemical isolation of quartz for measurement of in-situ -produced cosmogenic nuclides, Geochim. Cosmochim. Acta, 56, 3583-3587, doi:10.1016/00167037(92)90401-4, 1992.

Lal, D.: Cosmic ray labeling of erosion surfaces: in situ nuclide production rates and erosion models, Earth Planet. Sci. Lett., 104, 424-439, doi:10.1016/0012-821X(91)90220-C, 1991.

Lal, D. and Chen, J.: Cosmic ray labeling of erosion surfaces II: Special cases of exposure histories of boulders, soils and beach terraces, Earth Planet. Sci. Lett., 236, 797-813, doi:10.1016/j.epsl.2005.05.025, 2005.

Lal, D. and Chen, J.: Erratum to "Cosmic ray labeling of erosion surfaces II: Special cases of exposure histories of boulders, soils and beach terraces", Earth Planet. Sci. Lett., 241, 360, doi:10.1016/j.epsl.2005.11.002, 2006.

Lane, E. W. and Borland, W. M.: Estimating bed load, Transactions, Am. Geophys. Union, 32, 121-123, 1951.

Larsen, I. J., Almond, P. C., Eger, A., Stone, J. O., Montgomery, D. R. and Malcolm, B.: Rapid Soil Production and Weathering in the Southern Alps, New Zealand, Science, 343, 637-640, doi:10.1126/science.1244908, 2014.

Lupker, M., Blard, P.-H., Lavé, J., France-Lanord, C., Leanni, L., Puchol, N., Charreau, J. and Bourlès, D.: ${ }^{10}$ Be-derived Himalayan denudation rates and sediment budgets in the Ganga basin, Earth Planet. Sci. Lett., 333-334, 146-156, doi:10.1016/j.epsl.2012.04.020, 2012.

Malamud, B. D., Turcotte, D. L., Guzzetti, F., and Reichenbach, P.: Landslide inventories and their statistical properties, Earth Surf. Process. Landforms, 29, 687-711, doi:10.1002/esp.1064, 2004.

Merz, J.: Water Balances, Floods and Sediment Transport in the Hindu Kush-Himalayas, ICIMOD, Nepal, http://lib.icimod.org/ record/7484, 2004.

Milliman, J. D. and Syvitski, J. P. M.: Geomorphic/tectonic control of sediment discharge to the ocean: the importance of small mountainous rivers, J. Geol., 100, 525-544, doi:10.1086/629606, 1992.

Montgomery, D. R.: Soil erosion and agricultural sustainability, P. Natl. Acad. Sci. USA, 104, 13268-13272, doi:10.1073/pnas.0611508104, 2007.
Morgan, R. P. C.: Soil erosion and conservation, Blackwell, Oxford, 2005.

Morin, G., Fran, C., Gallo, F., Lupker, M., Lavé, J. and Gajurel, A.: Minor soil erosion contribution to denudation in Central Nepal Himalaya, Abstract from EGU General Assembly 2013, held $7-$ 12 April, 2013 in Vienna, Austria, EGU2013-12566, 2013.

Mutchler, C. K., Murphlee, C. E., and McGregor, K.: Laboratory and field plots for soil erosion studies, in Soil Erosion Research Methods, 9-36, SWCS/ISSS, St. Lucie Press, Delray Beach, FL, USA, 1970.

Niemi, N., Oskin, M., Burbank, D., Heimsath, A. and Gabet, E.: Effects of bedrock landslides on cosmogenically determined erosion rates, Earth Planet. Sci. Lett., 237, 480-498, doi:10.1016/j.eps1.2005.07.009, 2005.

Nishiizumi, K., Imamura, M., Caffee, M. W., Southon, J. R., Finkel, R. C. and McAninch, J.: Absolute calibration of ${ }^{10} \mathrm{Be}$ AMS standards, Nuclear Instruments and Methods in Physics Research Section B: Beam Interactions with Materials and Atoms, 258, 403-413, doi:10.1016/j.nimb.2007.01.297, 2007.

Ouimet, W.: Landslides associated with the May 12, 2008 Wenchuan earthquake: Implications for the erosion and tectonic evolution of the Longmen Shan, Tectonophysics, 491, 244-252, doi:10.1016/j.tecto.2009.09.012, 2009.

Pimentel, D., Harvey, C., Resosudarmo, P., Sinclair, K., Kurz, D., McNair, M., Crist, S., Shpritz, L., Fitton, L., Saffouri, R., and Blair, R.: Environmental and Economic Costs of Soil Erosion and Conservation Benefits, Science, 267, 1117-1123, doi:10.1126/science.267.5201.1117, 1995.

Portenga, E. and Bierman, P. R.: Understanding Earth's eroding surface with ${ }^{10} \mathrm{Be}$, GSA Today, 21, 4-10, 2011.

Pratt-Sitaula, B., Garde, M., Burbank, D. W., Oskin, M., Heimsath, A. and Gabet, E.: Bedload-to-suspended load ratio and rapid bedrock incision from Himalayan landslide-dam lake record, Quat. Res., 68, 111-120, doi:10.1016/j.yqres.2007.03.005, 2007.

Puchol, N., Lavé, J., Lupker, M., Blard, P.-H., Gallo, F., and France-Lanord, C.: Grain-size dependent concentration of cosmogenic ${ }^{10} \mathrm{Be}$ and erosion dynamics in a landslidedominated Himalayan watershed, Geomorphology, 224, 55-68, doi:10.1016/j.geomorph.2014.06.019, 2014.

Rapp, A.: Soil Erosion and Sedimentation in Tanzania and Lesotho, Ambio, 4, 154-163, 1975.

Reusser, L., Bierman, P., and Rood, D.: Quantifying human impacts on rates of erosion and sediment transport at a landscape scale, Geology, doi:10.1130/G36272.1, 2015.

Safran, E. B., Bierman, P. R., Aalto, R., Dunne, T., Whipple, K. X., and Caffee, M.: Erosion rates driven by channel network incision in the Bolivian Andes, Earth Surf. Process. Landforms, 30, 1007-1024, doi:10.1002/esp.1259, 2005.

Saunders, I. and Young, A.: Rates of surface processes on slopes, slope retreat and denudation, Earth Surf. Process. Landforms, 8, 473-501, doi:10.1002/esp.3290080508, 1983.

Schaller, M., Ehlers, T. A., Blum, J. D. and Kallenberg, M. A.: Quantifying glacial moraine age, denudation, and soil mixing with cosmogenic nuclide depth profiles, J. Geophys. Res., 114(F1), F01012, doi:10.1029/2007JF000921, 2009.

Scherler, D., Bookhagen, B., and Strecker, M. R.: Tectonic control on ${ }^{10} \mathrm{Be}$-derived erosion rates in the Garhwal Himalaya, India, J. Geophys. Res.-Earth, 119, 1-23, doi:10.1002/2013JF002955, 2014. 
Schreier, H., Brown, S., and MacDonald, J.: Too Little and Too Much: Water and Development in a Himalayan Watershed, IRES Press, Vancouver, 2006.

Shrestha, B. M., Singh, B. R., Sitaula, B. K., Lal, R. and Bajracharya, R. M.: Soil Aggregate- and Particle-Associated Organic Carbon under Different Land Uses in Nepal, Soil Sci. Soc. Am. J., 71, 1194-1203, doi:10.2136/sssaj2006.0405, 2007.

Shrestha, D. P.: Assessment of Soil Erosion in the Nepalese Himalaya, A Case Study of the Likhu Khola Valley, Middle Mountain Region, Land Husb. Oxf. IBH Publ., 2, 59-80, 1997.

Shrestha, D. P., Zinck, J. A., and Van Ranst, E.: Modelling land degradation in the Nepalese Himalaya, Catena, 57, 135-156, doi:10.1016/j.catena.2003.11.003, 2004.

Sitaula, B. K., Sankhayan, P. L., Bajracharya, R. M., and Singh, B. R.: A systems analysis of soil and forest degradation in a mid-hill watershed of Nepal using a bio-economic model, Land Degrad. Dev., 16, 435-446, doi:10.1002/ldr.671, 2005.

Smadja, J.: Studies of climatic and human impacts and their relationship on a mountain slope above Salme in the Himalayan Middle Mountains, Nepal, Mt. Res. Dev., 12, 1-28, doi:10.2307/3673745, 1992.

Stone, J. O.: Air pressure and cosmogenic isotope production, J. Geophys. Res.-Sol. Ea., 105, 23753-23759, doi:10.1029/2000JB900181, 2000.

Swanson, F. J. and Dyrness, C. T.: Impact of clear-cutting and road construction on soil erosion by landslides in the western Cascade Range, Oregon, Geology, 3, 393-396, doi:10.1130/00917613(1975)3<393:IOCARC>2.0.CO;2, 1975.

Tiwari, K. R., Sitaula, B. K., Bajracharya, R. M., and Børresen, T.: Runoff and soil loss responses to rainfall, land use, terracing and management practices in the Middle Mountains of Nepal, Acta Agr. Scand. B-S. P., 59, 197-207, doi:10.1080/09064710802006021, 2009.

Toy, T. J., Foster, G. R., and Renard, K. G.: Soil Erosion: Processes, Prediction, Measurement, and Control, John Wiley and Sones, New York., 2002.

Upadhaya, G. P., Sthapit, M., and Shrestha, K. N.: Runoff and soil loss studies in the Kulekhani Watershed: Results 1985-1990, in: Workshop Proceedings, Soil fertility and erosion issues in the Middle Mountain of Nepal, edited by: Shah, P. B., Shreier, H., Brown, S. J., and Riley, K. W., 25-32, 1991.
Vanacker, V., Bellin, N., Molina, A., and Kubik, P.: Erosion regulation as a function of human disturbances to vegetation cover: a conceptual model, Landscape Ecol, 29, 293-309, doi:10.1007/s10980-013-9956-z, 2014.

Vanacker, V., von Blanckenburg, F., Govers, G., Molina, A., Poesen, J., Deckers, J., and Kubik, P.: Restoring dense vegetation can slow mountain erosion to near natural benchmark levels, Geology, 35, 303-306, doi:10.1130/G23109A.1, 2007.

Van Dijk, A. I. J., and Bruijnzeel, L..: Terrace erosion and sediment transport model: a new tool for soil conservation planning in bench-terraced steeplands, Model. Hydrol. Syst., 18, 839-850, doi:10.1016/S1364-8152(03)00084-7, 2003.

Von Blanckenburg, F.: The control mechanisms of erosion and weathering at basin scale from cosmogenic nuclides in river sediment, Earth Planet. Sc. Lett., 242, 224-239, doi:10.1016/j.eps1.2005.06.030, 2006.

Von Blanckenburg, F., Hewawasam, T., and Kubik, P. W.: Cosmogenic nuclide evidence for low weathering and denudation in the wet, tropical highlands of Sri Lanka, J. Geophys. Res.-Earth, 109, F03008, doi:10.1029/2003JF000049, 2004.

West, A. J., Bickle, M. J., Collins, R., and Brasington, J.: Small-catchment perspective on Himalayan weathering fluxes, Geology, 30, 355-358, doi:10.1130/00917613(2002)030<0355:SCPOHW>2.0.CO;2, 2002.

West, A. J., Hetzel, R., Li, G., Jin, Z., Fei, Z., Hilton, R. G., and Densmore, A. L.: Dilution of ${ }^{10} \mathrm{Be}$ in detrital quartz by earthquake-induced landslides: implications for determining denudation rates and potential to provide insights into landslide sediment dynamics, Earth Planet. Sc. Lett., 396, 143-153, doi:10.1016/j.epsl.2014.03.058, 2014.

Wittmann, H. and von Blanckenburg, F.: Cosmogenic nuclide budgeting of floodplain sediment transfer, Geomorphology, 109, 246-256, doi:10.1016/j.geomorph.2009.03.006, 2009.

Wobus, C., Heimsath, A., Whipple, K., and Hodges, K.: Active outof-sequence thrust faulting in the central Nepalese Himalaya, Nature, 434, 1008-1011, doi:10.1038/nature03499, 2005.

Yanites, B., Tucker, G., and Anderson, R.: Numerical and analytical models of cosmogenic radionuclide dynamics in landslidedominated drainage basins, J. Geophys. Res., 114, F01007, doi:10.1029/2008JF001088, 2009. 